Review

\title{
Apoptosis in the Extraosseous Calcification Process
}

\author{
Federica Boraldi ${ }^{1, *(\mathbb{D})}$, Francesco Demetrio Lofaro ${ }^{1}$ and Daniela Quaglino ${ }^{1,2}$ (D) \\ 1 Department of Life Sciences, University of Modena and Reggio Emilia, 41125 Modena, Italy; \\ francescodemetrio.lofaro@unimore.it (F.D.L.); daniela.quaglino@unimore.it (D.Q.) \\ 2 Interuniversity Consortium for Biotechnologies (CIB), Italy \\ * Correspondence: federica.boraldi@unimore.it
}

\section{check for}

updates

Citation: Boraldi, F.; Lofaro, F.D.; Quaglino, D. Apoptosis in the Extraosseous Calcification Process. Cells 2021, 10, 131. https://doi.org/ 10.3390/cells10010131

Received: 10 December 2020 Accepted: 10 January 2021 Published: 12 January 2021

Publisher's Note: MDPI stays neutral with regard to jurisdictional clai$\mathrm{ms}$ in published maps and institutional affiliations.

Copyright: (C) 2021 by the authors. Licensee MDPI, Basel, Switzerland. This article is an open access article distributed under the terms and conditions of the Creative Commons Attribution (CC BY) license (https:// creativecommons.org/licenses/by/ $4.0 /)$.

\begin{abstract}
Extraosseous calcification is a pathologic mineralization process occurring in soft connective tissues (e.g., skin, vessels, tendons, and cartilage). It can take place on a genetic basis or as a consequence of acquired chronic diseases. In this last case, the etiology is multifactorial, including both extra- and intracellular mechanisms, such as the formation of membrane vesicles (e.g., matrix vesicles and apoptotic bodies), mitochondrial alterations, and oxidative stress. This review is an overview of extraosseous calcification mechanisms focusing on the relationships between apoptosis and mineralization in cartilage and vascular tissues, as these are the two tissues mostly affected by a number of age-related diseases having a progressively increased impact in Western Countries.
\end{abstract}

Keywords: ectopic mineralization; extracellular matrix; cell death; apoptosis; vascular tissue; cartilage

Apoptosis is a well-known type of programmed cell death normally occurring, either during development or aging, as a homeostatic mechanism controlling the cellular component within tissues by removing damaged or unnecessary cells under a wide variety of stimuli and conditions [1]. Dysregulation of apoptotic signaling and inappropriate apoptosis have been involved in the occurrence and progression of many diseases and of their complications, including ectopic calcification $[2,3]$.

More details on signals and on mechanisms that can induce apoptosis or, if removed prior to complete cell death, can reverse cell fate, are beyond the purpose of the present work (for extended reviews, see for instance [4-6]).

The calcification process is actively regulated by cells responsible for the formation, organization, and maintenance of the extracellular matrix and contributes to the deposition and accumulation of inorganic moieties $\left(\mathrm{Ca}^{2+}, \mathrm{Pi}, \mathrm{Mg}^{2+}, \mathrm{CO}_{3}\right)$. Mineralization is physiologically restricted to bones, teeth, growth plate, and deep layers of the articular cartilage under the coordinated action of inhibitory and stimulatory factors $[7,8]$. In pathologic conditions, mineralization also occurs in soft connective tissues. Extraosseous or ectopic calcification can be due to genetic mutations (e.g., Pseudoxanthoma elasticum, generalized arterial calcification of infancy, Familial chondrocalcinosis, and Familiar tumoral calcinosis) $[9,10]$ or can be the consequence of acquired chronic diseases (e.g., atherosclerosis, diabetes, chronic kidney disease, and osteoarthritis). Tissues mainly affected by aberrant mineralization are the cardiovascular system (i.e., vessels and valves) and the joints with diseases and clinical complications, which are the main cause of morbidity and mortality in the Western World and in the aging population, where a pro-osteogenic environment progressively takes place [11-14].

This review aims to provide an overview of extraosseous calcification mechanisms focusing on the relationships between apoptosis and mineralization in cartilage and vascular tissues.

\section{Extraosseous Calcification}

In physiological conditions, calcium $\left(\mathrm{Ca}^{2+}\right)$ and inorganic phosphate (Pi) exceed their solubility in most tissues; however, calcification does not occur in soft connective tissues 
for the presence of circulating and local inhibitors [15]. When these regulatory mechanisms are skimpy, pathological mineralization overwhelms and takes place through active cellmediated processes partially overlapping those observed during skeletal formation.

Although ectopic calcification can be due to mutation/s in a single or in few genes [9,10], in most cases, such as in aging and in several chronic degenerative disorders (e.g., atherosclerosis, diabetes, chronic kidney disease, and osteoarthritis), pathologic mineralization is multifactorial and involves a number of protein interactions and dysregulated signaling pathways [16,17]. On the basis of the pathogenic mechanism(s), extraosseous calcification is described as: (i) dystrophic, occurring in damaged tissues when serum calcium and phosphate are within a normal range [18]; (ii) metastatic, due to abnormal calcium and/or phosphate metabolism leading to hypercalcemia and/or hyperphosphatemia [18]; (iii) heterotopic ossification characterized by true bone tissue formed outside of the skeleton, as after surgery or traumatic injury [19]; (iv) calciphylaxis, often associated to endstage kidney disease and characterized by ischemic necrosis of the skin and calcification of the tunica media and fibrosis of the intima of cutaneous arterioles associated with thrombotic occlusion [20].

In hard tissues, minerals are mainly deposited as hydroxyapatite, in contrast, in soft connective tissues, crystals of different compositions have been described (Table 1).

Table 1. Type of crystals found in extraosseous calcification.

\begin{tabular}{|c|c|c|c|c|}
\hline Mineral & Short Name & Chemical Formula & $\begin{array}{l}\text { Mineralization } \\
\text { Site }\end{array}$ & References \\
\hline $\begin{array}{l}\text { Amorphous } \\
\text { calcium } \\
\text { phosphate }\end{array}$ & APC & $\mathrm{Ca}_{9}\left(\mathrm{PO}_{4}\right)_{6}$ & $\begin{array}{c}\text { Atherosclerotic } \\
\text { plaque, aortic } \\
\text { valves, and } \\
\text { brain }\end{array}$ & [21-23] \\
\hline $\begin{array}{l}\text { Brushite or } \\
\text { dicalcium } \\
\text { phosphate } \\
\text { dihydrate }\end{array}$ & DCPD & $\mathrm{CaHPO}_{4} \cdot 2\left(\mathrm{H}_{2} \mathrm{O}\right)$ & $\begin{array}{l}\text { Heart valves } \\
\text { and kidney } \\
\text { stones }\end{array}$ & {$[24,25]$} \\
\hline $\begin{array}{l}\text { Calcium } \\
\text { carbonate }\end{array}$ & $\mathrm{CaCO}$ & $\begin{array}{c}\mathrm{Ca}_{10}\left(\mathrm{PO}_{4}\right)_{6}(\mathrm{OH})_{2-2 \mathrm{x}}\left(\mathrm{CO}_{3}\right)_{\mathrm{x}} \\
\mathrm{Ca}_{10-\mathrm{x}}\left(\mathrm{PO}_{4}\right)_{6-\mathrm{x}}\left(\mathrm{CO}_{3}\right)_{\mathrm{x}}(\mathrm{OH})_{2-\mathrm{x}}\end{array}$ & Tendons & [26] \\
\hline $\begin{array}{l}\text { Calcium } \\
\text { oxalate }\end{array}$ & $\mathrm{CaOx}$ & $\mathrm{CaC}_{2} \mathrm{O}_{4}$ & $\begin{array}{l}\text { Breast, renal } \\
\text { stones, and } \\
\text { vascular }\end{array}$ & {$[27,28]$} \\
\hline $\begin{array}{l}\text { Calcium py- } \\
\text { rophosphate } \\
\text { dihydrate }\end{array}$ & CPPD & $\mathrm{Ca}_{2} \mathrm{P}_{2} \mathrm{O}_{7}$ & $\begin{array}{l}\text { Knee joint, } \\
\text { meniscus, and } \\
\text { tendons }\end{array}$ & [29-32] \\
\hline Hydroxyapatite & HA & $\left(\mathrm{Ca}_{10}\left(\mathrm{PO}_{4}\right)_{6} \mathrm{OH}_{2}\right)$ & $\begin{array}{l}\text { Aortic valve, } \\
\text { brain, } \\
\text { cardiovascular } \\
\text { tissue, kidney, } \\
\text { skin, and } \\
\text { tendons }\end{array}$ & {$[23,33-37]$} \\
\hline $\begin{array}{l}\text { Tricalcium } \\
\text { phosphate }\end{array}$ & TCMP & $\mathrm{Ca}_{3}\left(\mathrm{PO}_{4}\right)_{2}$ & $\begin{array}{l}\text { Breast and } \\
\text { tendons }\end{array}$ & {$[26,38]$} \\
\hline $\begin{array}{l}\text { Octacalcium } \\
\text { phosphate }\end{array}$ & $\mathrm{OCP}$ & $\mathrm{Ca}_{8}\left(\mathrm{HPO}_{4}\right)_{2}\left(\mathrm{PO}_{4}\right)_{4} \cdot 5 \mathrm{H}_{2} \mathrm{O}$ & $\begin{array}{c}\text { Heart valves, } \\
\text { knee joint } \\
\text { compartments }\end{array}$ & {$[24,39,40]$} \\
\hline Whitlockite & WH & $\mathrm{Ca}_{18} \mathrm{Mg}_{2}\left(\mathrm{HPO}_{4}\right)_{2}\left(\mathrm{PO}_{4}\right)_{12}$ & $\begin{array}{l}\text { aorta, breast, } \\
\text { cartilage, } \\
\text { prostate, } \\
\text { salivary glands }\end{array}$ & [41-46] \\
\hline
\end{tabular}

There are several patho-mechanisms responsible for ectopic calcification, as altered hormonal homeostasis [47], dysregulated angiogenesis and/or vascular repair mechanisms [48], and abnormal extracellular nucleotide metabolism [49,50]. More recently, a number of investigations have focused on the release of membrane vesicles, on the role of modified mitochondria-related pathways, and on the influence of oxidative stress on the occurrence and progression of soft connective tissue mineralization, as detailed in the following sections of the present review. 


\subsection{Membrane Vesicles}

Membrane vesicles (also known as extracellular vesicles) are phospholipid-enclosed nanoparticles (30-2000 nm), that, based on their diameter and biogenesis, are comprised of: (i) exosomes (30-150 nm) of endosomal origin; (ii) matrix vesicles (or microvesicles, $50-1000 \mathrm{~nm}$ ) generated by blebbing of the plasma membrane; (iii) apoptotic bodies (500-2000 nm) released from dying cells [51,52].

Matrix vesicles (MVs) are small spherical bodies of cellular origin found in association with crystal deposits. However, MVs' biogenesis is still under investigation as they could have a different origin depending on the cellular type as well as on the chemical and osmotic characteristics of the extracellular matrix. Some authors have identified vascular smooth muscle cells-derived MVs as exosomes [53], whereas other studies, performed on chondrocytes and osteoblasts [54-57], indicate that MVs originate from the cellular plasma membrane (Figure 1). MVs have been found in soft connective tissues (e.g., in calcific valvular stenosis, atherosclerosis) with structure/composition similar to skeletal MVs [57-59], suggesting that the mechanisms of extraosseous calcification are similar to those observed in normal skeletal development [60].

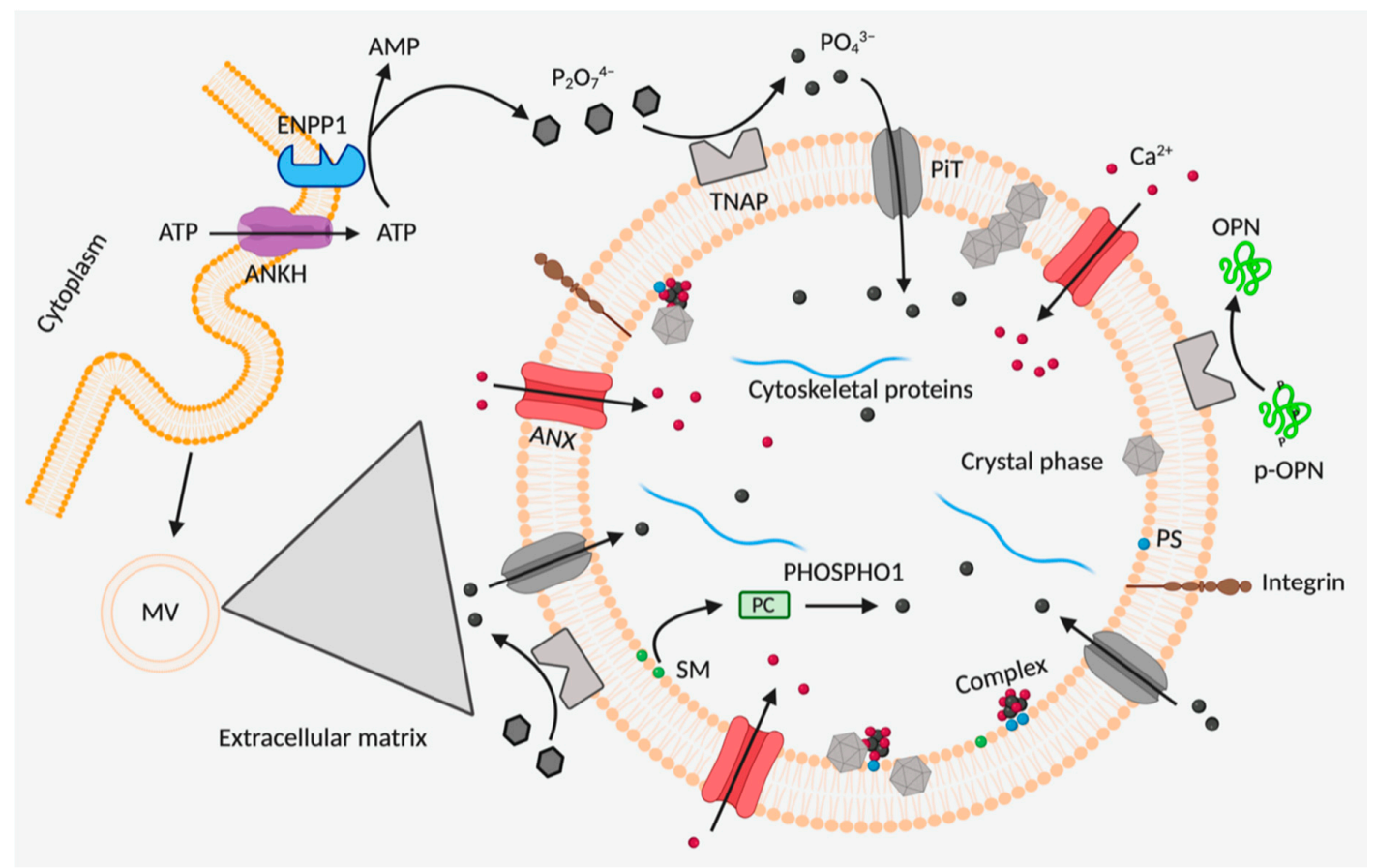

Figure 1. MVs. Mineral deposition is initiated by accumulation of calcium $\left(\mathrm{Ca}^{2+}\right)$ and inorganic phosphate $\left(\mathrm{PO}_{4}{ }^{3-}\right)$ into matrix vesicles (MVs) (for more details see the text) Abbreviations: ANKH = progressive ankylosis protein homolog, ANX = annexin; ENPP1 = nucleotide pyrophosphatase phosphodiesterase; OPN = osteopontin; $\mathrm{PC}=$ phosphocholine; $\mathrm{PiT}=$ phosphate transporter; $\mathrm{P}_{2} \mathrm{O}_{7}{ }^{4-}=$ pyrophosphate; $\mathrm{PS}=$ phosphatidylserine; TNAP = tissue non-specific alkaline phosphatase; $\mathrm{SM}=$ sphingomyelin.

As initiators of calcification, MVs contain either regulators of phosphate homeostasis, or proteins and lipids serving as nucleation sites for crystal deposition [56]. By proteomic analysis it has been demonstrated that MVs contain several enzymes (tissue non-specific alkaline phosphatase ( $A L P / \mathrm{TNAP})$, nucleotide pyrophosphatase phosphodiesterase (NPP1 /ENPP1), phosphoethanolamine / phosphocholine phosphatase (PHOSPHO1), Na+/K+ ATPase, metalloproteinases (MMP-2, -3, and -13)], transport proteins (annexins (ANXs) as ANX II, V, and VI); sodium-dependent inorganic phosphate transporters (PiT-1, -2) and other proteins (integrins) and lipids (i.e., phosphatidylserine and phosphatidylethanolamine) [61]. MVs enzymes (TNAP and ENPP1), together with the cell associated progressive ankylosis protein homolog (ANKH), actively contribute to ectopic 
calcification. In particular, ANKH has been reported to regulate levels of extracellular and intracellular inorganic phosphate ( $\mathrm{Pi})$, transporting pyrophosphate $(\mathrm{PPi})$, a strong inhibitor of soft connective tissue calcification $[62,63]$ or, according to other studies, transporting ATP $[64,65]$ that can be later converted to PPi by ENPP1. This last enzyme converts extracellular nucleoside triphosphates to AMP and PPi, whereas TNAP creates a pro-osteogenic environment by: (1) hydrolyzing PPi and enhancing extracellular inorganic phosphate (Pi) concentration, a mineralization promoter; and (2) modulating the phosphorylation of the non-collagenous bone protein osteopontin (OPN), that, in its phosphorylated status, inhibits hydroxyapatite formation and growth [66]. Pi levels into MVs are governed both by the Pi influx through PiT-1 and by the Pi generated from MVs membrane lipids (i.e., phosphocholine, phosphoethanolamine). These lipids are engendered from the membranes through the action of phospholipases and then release intra-vesicular Pi upon hydrolysis by PHOSPHO-1 [67].

$\mathrm{Ca}^{2+}$ influx into MVs occurs through ANX channels. The high concentration of calcium and phosphate into MVs triggers their precipitation, followed by mineral stabilization due to the binding of crystals to phosphatidylserine, an anionic phospholipid with high affinity for $\mathrm{Ca}^{2+}$. Initially, these complexes are made of amorphous calcium phosphate, which is progressively transformed into hydroxyapatite [68]. Crystals, along their growth, can destroy $\mathrm{MVs}^{\prime}$ membranes and are released into the extracellular matrix, where they interact with $\mathrm{Ca}^{2+}$ and $\mathrm{PO}_{3}{ }^{-4}$ moieties continuing their growth $[56,61,69]$.

Annexins are expressed in many different cell types and exert many functions, including exocytosis, membrane fusion, ion channels, and receptors for extracellular matrix proteins (e.g., collagens type I, II, and X and proteoglycans). In particular, ANX II, V and VI, not only mediate $\mathrm{Ca}^{2+}$ influx into MVs, but they form $\mathrm{Ca}^{2+}$ channels also in hypertrophic growth plate chondrocytes leading to the influx of $\mathrm{Ca}^{2+}$, stimulation of terminal differentiation, including up-regulation of specific genes, the release of MVs, induction of matrix mineralization and apoptosis [70].

Similarly to MVs, apoptotic bodies (ABs) can be the initiators of the mineralization process [71-73]. However, ABs, if compared to MVs, exhibit some differences in size, structure and composition [74]. In particular, ABs do not contain or contain only a few ANX II, V, and VI, which, in this context, are not required for calcification. It has been shown that, after blocking ANX channel activities with specific antibodies, ABs accumulate calcium on their outer membrane surface [73], where phosphatidylserine is exposed, allowing calcium binding. Therefore, ABs and MVs use different mechanisms to induce calcification: the first mineral phase occurs inside MVs, whereas it takes place on the outer membrane surface in ABs [16,74].

\subsection{Mitochondria and Oxidative Stress}

Ultrastructural observations, performed already in the 1970s, demonstrated the presence of hydroxyapatite deposition within mitochondria in bone as well as in soft connective tissue, thus highlighting the relationship between these organelles and the calcification process [75]. Mitochondria are key players in cellular energy metabolism, produce adenosine triphosphate (ATP) and a number of biosynthetic intermediates, participate in the redox balance and are involved in autophagy and apoptosis [76] and may also be regarded as initiators of intracellular calcification [77]. Within mitochondria, several mineral inclusions can be found in the form of needle-shaped crystals or of fine granules [77-79]. The former start to be deposited close to the cristae and later spread to the whole mitochondrial matrix, whereas the latter begin to develop in the mitochondrial matrix and thereafter grow close to cristae [77]. To be noted that dense granules of calcium-phosphate have been observed within mitochondria of many different cell types, thus indicating that these findings are not peculiar for a specific cell type [80-82]. Mitochondria initiate calcification through the interaction of phosphatase enzymes, including alkaline phosphatase, with calcium-binding phospholipids forming Ca- and P-rich electron-dense granules, which are released from cells to mineral nucleation sites in the extracellular space $[83,84]$. 
More recent investigations revealed that mitochondria further contribute to ectopic calcification producing reactive oxygen species (ROS), thus causing oxidative stress damage and promoting mitochondria-mediated apoptosis and subsequent calcification. Within cells, mitochondria undergo continuous changes alternating fusion and fission events [85], fission events being associated with calcification. In particular, dynamin-related protein 1 is the main player in mitochondrial fission, and its activity is regulated by different posttranslational modifications (e.g., phosphorylation, ubiquitination, and S-nitrosylation) [86].

Suppression of mitochondrial fission reduces apoptosis, ROS, runt-related transcription factor 2 (Runx2) protein expression, and calcium deposition, thus inhibiting extraosseous mineralization [87].

The source of ROS is not limited to mitochondria. Together with reactive nitrogen species (RNS), ROS are produced in various cell compartments (cell membrane, cytoplasm, endoplasmic reticulum, and peroxisomes) by enzymes such as nicotinamide adenine dinucleotide phosphate oxidases, nitric oxide synthase (NOS), xanthine oxidase, cytochrome P450 and cyclo-oxygenase [88] (Figure 2A). The redox signaling mechanisms activated by hydrogen peroxide $\left(\mathrm{H}_{2} \mathrm{O}_{2}\right)$ and radical peroxynitrite $\left(\mathrm{ONOO}^{-}\right)$are similar, although $\mathrm{ONOO}^{-}$has higher reactivity. In particular, $\mathrm{ONOO}^{-}$, once protonated, can be: (i) activated by homolysis forming hydroxyl radical plus nitrogen dioxide radical; (ii) degraded by isomerization to nitrate (Figure $2 \mathrm{~A}$ ). Under physiological conditions, ROS and RNS production is tightly regulated by antioxidant enzymes; however, when their formation exceeds the antioxidant capacity of cells and tissues, an oxidative stress condition takes place. Even though ROS/RNS are known to be deleterious for cells, they also represent important and necessary signaling molecules [89,90]. Therefore, the balance between oxidant/antioxidant molecules must be finely tuned to avoid uncontrolled signaling mechanisms as demonstrated, for instance, by nuclear factor kappa-light-chain-enhancer of activated B cells (NF- $\mathrm{B}$ ), which is up- or down-regulated by ROS/RNS in concentrationand cell-dependent manners [91,92].

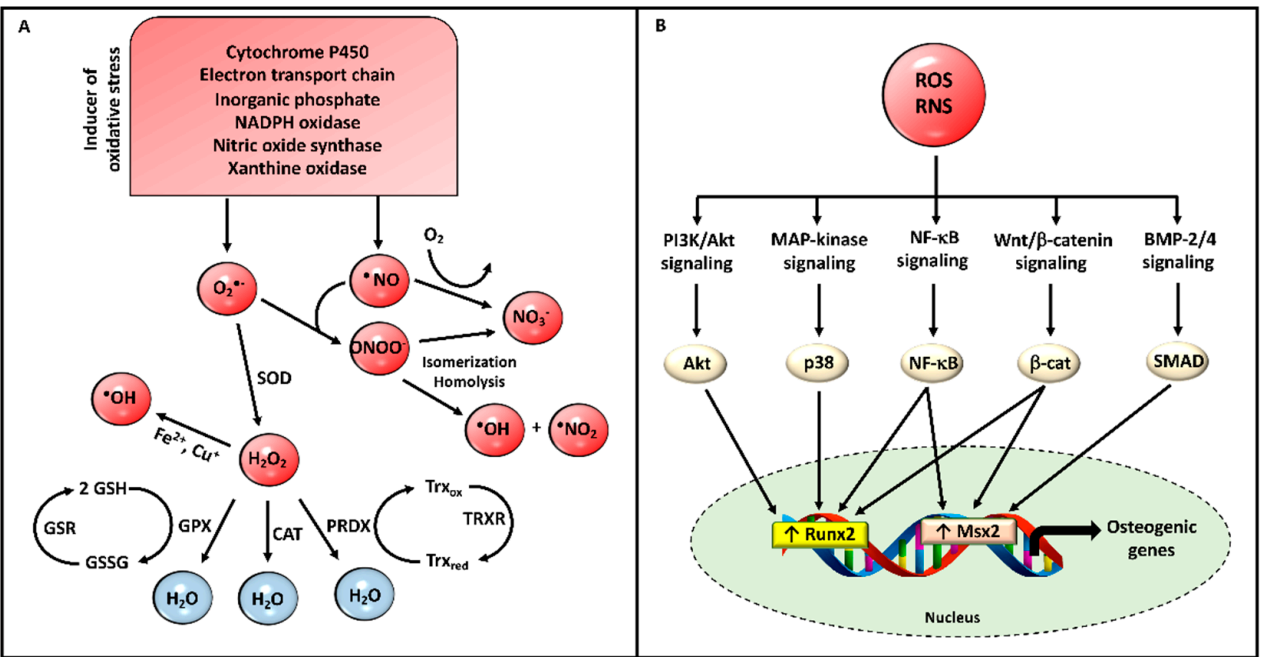

Figure 2. (A) Generation of ROS and RNS. When ROS and RNS production exceeds the capacity of antioxidant systems, an oxidative stress condition is created, which causes damage to the macromolecules (i.e., nucleic acids, proteins, carbohydrates, and lipids). (B) Signal transduction pathways regulated by ROS and RNS. The activation of these pathways induces nuclear translocation of transcription factors, which lead to the activation of osteogenic genes. Abbreviations: ROS = reactive oxygen species; RNS = reactive nitrogen species; $\mathrm{BMP}-2 / 4=$ bone morphogenetic protein-2 and $-4, \mathrm{CAT}=$ catalase, GPX = glutathione peroxidase, $\mathrm{GSH}=$ reduced glutathione, $\mathrm{GSR}=$ glutathione disulfide reductase, GSSG = glutathione disulfide, $\mathrm{H}_{2} \mathrm{O}_{2}=$ hydrogen peroxide, $\mathrm{O}_{2}{ }^{\bullet-}=$ superoxide anion, ${ }^{\bullet} \mathrm{OH}=$ hydroxyl radical, $\mathrm{ONOO}^{-}=$radical peroxynitrite, Msx2 = muscle segment homeobox $2,{ }^{\bullet} \mathrm{NO}=$ nitric oxide, ${ }^{\bullet} \mathrm{NO}_{2}=$ nitrogen dioxide radical; $\mathrm{NO}_{3}{ }^{-}=$nitrate; $\mathrm{NF}-\mathrm{kB}=$ nuclear factor kappa-light-chain-enhancer of activated $\mathrm{B}$ cells, $\mathrm{PI} 3 \mathrm{~K} / \mathrm{Akt}=$ phosphatidylinositol 3-kinase/protein kinase-B, PRDX = peroxiredoxin, Runx2 = runt-related transcription factor 2, SOD = superoxide dismutase, $\operatorname{Tr} x_{\text {red }}=$ reduced thioredoxin, $\operatorname{Tr} x_{o x}=$ oxidized thioredoxin, $\operatorname{Tr} x R=$ thioredoxin reductase. 
Mitochondrial ROS and RNS have been shown to activate NF- $\mathrm{kB}$ and NF- $\mathrm{kB}$-dependent osteo-inductive signaling pathways (Figure 2B) [91,93]. NF- $\mathrm{kB}$ is located in the cytoplasm in a latent form that binds to several inhibitory proteins ( $\mathrm{I} \mathrm{KBs}$ ) and can be activated by classical or alternative pathways [92]. Therefore, in response to several stimuli, IKB is phosphorylated, leading to its ubiquitination and proteasomal degradation. Subsequently, NF-KB is free to translocate into the nucleus and to bind to NF- $\mathrm{kB}$-responsive elements, up- or down-regulating the expression of osteogenic factors (e.g., $A L P$ ) and anti-mineralization proteins (e.g., ANKH), respectively [93]. Several studies, performed in in vitro and in vivo calcification models, have highlighted that inhibition/suppression of NF- $\mathrm{KB}$ can reduce mineralization [93-95]. Moreover, NF- $\mathrm{kB}$ inhibits glycogen synthase kinase- $3 \beta$ determining the activation of the canonical Wnt pathway that can also be directly activated by ROS and RNS [96,97], controlling numerous cellular processes, as osteogenic trans-differentiation [98] and calcification [99].

Oxidative stress up-regulates the expression of Runx2 through the activation of the phosphatidylinositol 3-kinase/protein kinase-B/Runx2 signaling pathway (PI3K/AKT/Runx2) or the p38 MAP kinase signaling pathway $[91,99]$ leading to osteogenic trans-differentiation and promoting calcification [100,101] (Figure 2B). Moreover, ROS/RNS up-regulate bone morphogenetic protein-2 and -4 (BMP2 and BMP4) expression [102-104], which, through SMADs, act on several transcription factors such as Runx2, muscle segment homeobox 2 (Mxs2), and osterix, essential for pro-osteoblastic differentiation (Figure 2B) [105]. Consistently, Runx2 induces the expression of bone matrix proteins such as collagen type I, osteocalcin (OC), OPN, bone sialoprotein, and TNAP activity [106,107].

\section{Apoptosis and Cartilage Calcification}

Articular cartilage is typically composed of chondrocytes embedded within a rather amorphous extracellular matrix (ECM) comprised of collagen (mainly type II), different proteoglycans (e.g., perlecan, aggrecan), structural proteins involved in cell-matrix and matrix-matrix interactions (e.g., cartilage matrix protein, fibronectin), proteinases and their inhibitors [108].

Endochondral ossification, a physiologic mechanism occurring during skeletal development, is essential in growth plates of developing long bones [109], in the antlers of deers [110], and at the tendon and ligament insertions into bones [111]. It is a complex multistep process orchestrated by chondrocytes undergoing a sequence of events (proliferation, hypertrophy, terminal differentiation, and cell death), and it is restricted to regions of terminally differentiated chondrocytes (i.e., areas close to chondro-osseous junctions) [112]. In particular, hypertrophic chondrocytes are involved in the regulation of cartilage remodeling and calcification as well as in the bone vascularization process, producing collagen type $\mathrm{X}$ and activating osteoblast-related genes (e.g., MMP-13, ALP, OPN, bone sialoprotein, osterix, OC, and Runx2) [113]. These cells undergo osteogenic trans-differentiation releasing MVs into the ECM and initiating the calcification process [114-116].

Changes in these pathways may lead to pathologic conditions, as in osteoarthritis $(\mathrm{OA})$, the most common degenerative joint disease in older individuals, which can be considered a paradigmatic model of aberrant cartilage calcification due to unbalanced cartilage homeostasis due to excessive catabolic activity. During OA progression, chondrocytes undergo important phenotypic changes and exhibit an abnormally increased rate of maturation [117]. Hypertrophic chondrocytes, as observed in the growth plate, acquire a more catabolic phenotype increasing the secretion of degradative enzymes such as MMP-13 and a disintegrin and metalloproteinase with thrombospondin motifs (ADAMTS)- 4 and -5, which destroy the ECM. Degradation of cartilage ECM proteins (e.g., collagen and fibronectin), secretion of damage-associated molecular patterns (DAMPs) and alarmins (e.g., calgranulins S100A8 and S100A9) can induce an inflammatory response [118] with the release of cytokines, $\mathrm{NO}$ and ROS, which, in turn, increase chondrocyte catabolism. Therefore, chondrocyte catabolism, tissue degradation, and inflammation contribute to the severity of OA [119]. 
The observation that in OA there are numerous empty lacunae and hypocellularity have suggested that chondrocyte cell death can participate in the pathogenesis of OA $[72,120,121]$. Consistently, in OA increased chondrocyte death was detected compared to healthy cartilage [122-124], and both apoptotic and necrotic mechanisms have been described [120,125-127]. Roach et al. [128] coined the term "chondroptosis", to indicate a specific form of death, in which cells are characterized by shrunk and condensed chromatin, increased rough endoplasmic reticulum and Golgi apparatus, and the presence of autophagic vacuoles. Interestingly, during the early stages of OA, the superficial layer and the middle zone of cartilage are characterized by increased death of chondrocyte due to a combination of apoptosis and autophagy, the latter as an adaptative mechanism activated in sublethal conditions that may lead to cell death after a point of no return $[127,129]$. By contrast, in the deeper zone, in both human and animal OA models, apoptotic cell death was revealed associated with abnormal cartilage calcification [129,130].

According to some authors, a positive correlation exists between apoptosis and severity of cartilage damage $[120,121,126,127,131]$ and different molecular signals (Figure 3) can induce chondrocyte apoptosis, even if it has not yet been clarified whether apoptosis is the final step in the terminal differentiation of articular chondrocytes or whether it occurs independently [124]. As a consequence of chondrocyte apoptosis, there is the formation of ABs, which, remaining in the lacunae of chondrocytes, release their content (e.g., nucleotide pyrophosphohydrolase and alkaline phosphatase) [72] and may trigger the mineralization process.

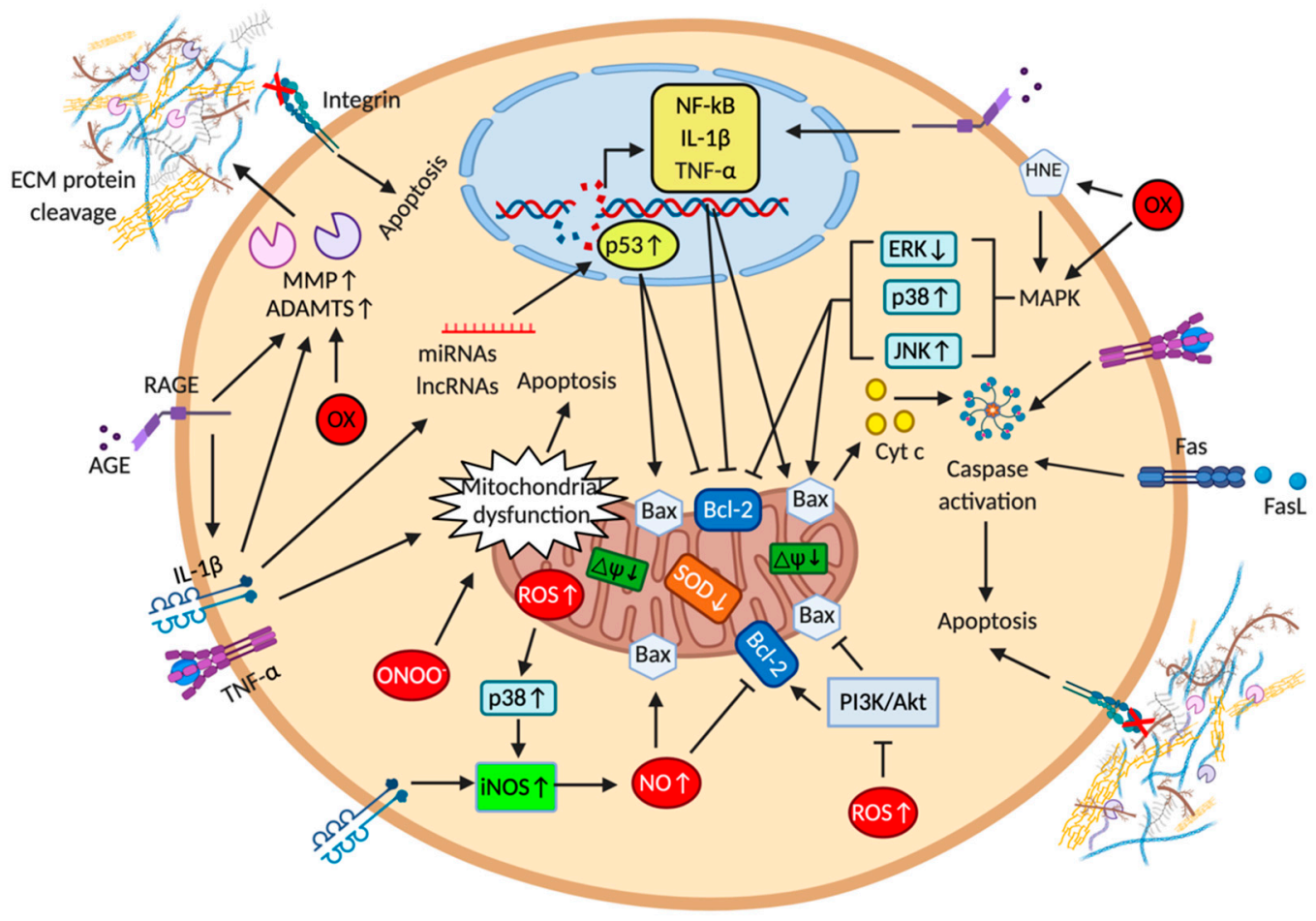

Figure 3. Schematic representation of extrinsic and intrinsic factors involved in chondrocyte apoptosis. Abbreviations: ADAMTS = disintegrin and metalloproteinase with thrombospondin motifs; AGE = advanced glycation end products; Bax $=$ Bcl-2-associated $\mathrm{X} ; \mathrm{Bcl}-2=\mathrm{B}$-cell lymphoma protein 2; Cyt c = cytochrome $\mathrm{c}, \Delta \Psi=$ mitochondrial membrane potential, $\mathrm{ECM}=$ extracellular matrix; ERK = extracellular-signal-regulated kinase; FasL = Fas ligand; HNE = 4-hydroxynonenal; IL-1 $\beta$ = interleukin 1 beta; iNOS = inducible nitric oxide synthases; JNK = c-Jun N-terminal kinases; LncRNAs = long non-coding RNA; MAPK = mitogen-activated protein kinase; miRNAs = microribonucleic acids; $\mathrm{MMP}=$ matrix metalloproteinases; $\mathrm{NF}-\mathrm{KB}=$ nuclear factor kappa-light-chain-enhancer of activated $\mathrm{B}$ cells; $\mathrm{NO}=$ nitric oxide; $\mathrm{ONOO}^{-}=$radical $^{-}$ peroxynitrite, $\mathrm{OX}=$ oxidative stress; $\mathrm{PI} 3 \mathrm{~K} / \mathrm{Akt}=$ phosphatidylinositol 3-kinase/protein kinase-B; RAGE = receptor for advanced glycation end products, ROS = reactive oxygen species; SOD = superoxide dismutase; TNF- $\alpha=$ tumor necrosis factor alpha. 
It is worth mentioning that cartilage is avascular, and therefore, the inflammatoryderived degradative process is related to persistent infiltration of leucocytes from surrounding tissues and to the presence of cytokines and mediators in the synovial fluid. Interestingly, one study showed that, in the early stages of OA, some chondrocytes, isolated from degenerated rat cartilage and expressing type II collagen+/CD163+, had phagocytic activity and, therefore, might have a role in the clearance of dead chondrocytes. However, these cells disappear during OA progression [132].

Further studies have supported the finding that in addition to chondrocyte-derived $\mathrm{ABs}$, also MVs released by hypertrophic chondrocytes participate in pathological cartilage mineralization $[30,56,72,133,134]$. For example, ABs isolated from cultured chondrocytes treated with NO or anti-Fas, as inducers of chondrocyte apoptosis [135,136], are capable of promoting in vitro mineralization [72]. A study performed on knee articular cartilage from OA and control samples showed, in patients, the co-presence of chondrocyte apoptosis and of hydroxyapatite (HA) microcrystals, highlighting the connection between apoptosis and ectopic mineralization [126].

In in vitro models, in the absence of endogenous pro-osteogenic stimuli, addition to the culture medium of $\mathrm{Pi}$ or $\beta$-glycerophosphate is required to induce and/or stimulate the calcification process [137-140] as demonstrated in ATDC5 chondrocytes, where Pi supplementation accelerates terminal chondrocyte differentiation and induces apoptosisdependent mineralization. Moreover, the ability of a caspase inhibitor to reduce crystal formation indicated that calcification was, at least partially, dependent on caspase activity [141]. Recently, it has been shown that, under oxidative stress, ABs derived from endplate chondrocytes up-regulated the expression of osteocalcin, RUNX2, and ALP and down-regulated ENPP1 and ANK expression, implying that oxidative stress and ABs alter PPi metabolism, increasing Pi content [142].

Interestingly, it has been observed that calcium-phosphate crystals (e.g., OCP and HA) exerted an amplifying role in chondrocyte apoptosis $[135,143]$. In particular, chondrocytes were capable of engulfing crystals, which were dissolved into lysosomes determining an increase of $\mathrm{Ca}^{2+}$ intracellular levels [144,145], this ion being a positive regulator of chondrocyte differentiation, apoptosis, and mineralization [146]. Moreover, calcium-phosphate crystals are closely associated with cartilage degradation because they up-regulate the expression of cytokines (e.g., IL-6) and of cartilage-degrading enzymes (e.g., MMP-13 and collagenase), thus condition cell fate and behavior [147,148].

\subsection{Extracellular Matrix Components in the Context of Cartilage Apoptosis}

Studies performed on human and animal chondrocytes have demonstrated that changes in matrix components can trigger chondrocytes cell death and that several risk factors (e.g., traumatic joint injury, physical activity, genetics, age, and obesity) are related to increased catabolic processes that through pro-inflammatory cytokines, degradative enzymes, loss, and breakdown of matrix constituents sustain the perpetuation of a catabolic cycle starting from the superficial zone and proceeding towards the deeper zone [149,150]. In particular, in OA cartilage, it has been observed a disruption, driven by MMP-13 and ADAMTS-4 and -5 , of the network comprised of collagen type II, aggrecan, fibronectin, hyaluronan, and other non-collagenous matrix proteins [151], determining the formation of ECM protein fragments [152-154] which induce an inflammatory response, an increase of catabolic proteases (e.g., collagenases, aggrecanases, hyaluronidases) and induction of apoptosis (Figure 3). Moreover, age-related accumulation of advanced glycation end products (AGE) may further contribute to cartilage damage $[155,156]$ as demonstrated in OA cartilage by Loeser and collaborators [157], showing increased expression of AGE receptors (RAGE) were associated with activated inflammatory pathways and increased MMP-13 production.

Because the cartilaginous ECM plays a crucial role in regulating cell growth, differentiation, adhesion, and survival, degeneration and loss of cartilage matrix can modify the ability of chondrocytes to adhere to ECM. For instance, cleaved collagen type II can induce, 
in vitro, a significant increase of chondrocyte apoptosis [158]. Consistently, it has been demonstrated that integrins, transmembrane receptors involved in cell-matrix interactions, can mediate cell survival, preventing apoptosis [159], as demonstrated in chondrocytes cultured on fibronectin, which underwent apoptosis when anti- $\alpha 5 \beta 1$ integrin antibodies were added to the medium [160]. Similarly, in OA animal models, changes in the expression and localization of $\alpha 2, \alpha 4$, and $\alpha 5$ integrins were observed [161], and increased expression of MMP-2 and MMP-3 associated with cell reduction and increased apoptosis compared to wild-type (WT) mice have been detected in the cartilage of $\alpha 1-\mathrm{KO}$ mice [162].

Altogether, these data indicate that altered cartilage matrix composition and organization and chondrocyte apoptosis can generate a feedback loop where the progression of one worsens the other.

\subsection{Death Receptors and Cytokines in the Context of Cartilage Apoptosis}

Apoptosis is typically triggered by the interactions between Fas and Fas ligand (FasL), members of the tumor necrosis factor (TNF)-receptor and TNF family, respectively (Figure 3). Fas is a transmembrane protein containing a cytoplasmic death domain essential for the induction of apoptosis, therefore binding between FasL and Fas determines the recruitment of the adaptor protein Fas-associated death domain, which recruits caspase- 8 and caspase- 10 to form the death-inducing signaling complex. Caspase- 8 , in turn, induces apoptosis by two pathways: (i) activating caspase- 3 or (ii) cleaving $\mathrm{BH} 3$ interacting death domain agonist and consequently inducing mitochondrial dysfunction with cytochrome-c release and caspases- 9 and -3 activation.

It has been demonstrated that, in the early stages of OA, hypocellularity is associated with enhanced levels of Fas, FasL, and caspase-8 [163,164]. Consistently, chondrocytes from OA damaged areas have higher Fas expression than those from non-lesioned areas [165]. Interestingly, in human and in mouse OA cartilage, a correlation was found between apoptosis and the transcription factor hypoxia-inducible factor (HIF)- $2 \alpha$ through enhanced Fas expression $[166,167]$.

Moreover, several in vitro and in vivo studies have demonstrated that pro-inflammatory cytokines, such as TNF- $\alpha$ and IL- $1 \beta$, are produced by chondrocytes and play a key role in OA pathogenesis [168]. These cytokines: (i) induce the over-expression of MMP-1, -3 , -13 and ADAMTS-5, favoring proteolysis and cartilage ECM loss [169,170]; (ii) prevent the normal production of collagen type II and aggrecan [170,171]; (iii) stimulate NO and cyclooxygenase-2 production contributing, indirectly, to chondrocyte cell-death [172]; (iv) induce autocrine production of IL- $1 \beta$ and TNF- $\alpha$ [173]; and (v) cause mitochondrial dysfunction, reducing mitochondrial DNA (mtDNA) integrity and mtDNA repair capacity, which correlates with increased chondrocyte apoptosis $[174,175]$. Finally, it has been demonstrated that TNF- $\alpha$-induced chondrocytes apoptosis is dependent on the balance between survival (i.e., ERK1/2) and death (i.e., p38 MAPK and JNK) signaling pathways $[176,177]$.

\subsection{Mitochondria and Reactive Oxygen and Nitrogen Species in the Context of Cartilage Apoptosis}

Mitochondria play a crucial role in cellular function and survival, and the alterations in mitochondrial structure and function (e.g., increase in membrane permeability, depolarization, decrease in ATP production, and the release of cytochrome c) precede the classic signs of cell death $[178,179]$. Compared to normal chondrocytes, those from OA cartilage show diminished efficiency of electron transfer pathways associated with mitochondrial membrane depolarization, which led to apoptosis following caspase- 9 activation and release of cytochrome $c$ from the inner mitochondrial membrane to the cytosol $[178,180]$. In addition, proteomic analysis showed in OA chondrocytes higher ROS levels [181] and a significant decrease of manganese-superoxide dismutase (Mn-SOD), a mitochondrial antioxidant enzyme (Figure 3). The treatment of chondrocytes with antioxidants, preventing oxidative stress- derived mitochondrial damage, efficiently reduced apoptosis [182].

Interestingly, $\mathrm{Ca}^{2+}$ influx is important in apoptosis as it is able to induce ROS generation, mitochondrial depolarization, and mtDNA damage [183]. Transient receptor potential 
ankyrin 1 (TRPA1), a membrane-associated cationic channel, can be activated by RNS and ROS [184], causing an influx of cation ions, in particular of $\mathrm{Ca}^{2+}$. TRPA1 expression is up-regulated in primary human OA chondrocytes by inflammatory cytokines (e.g., IL-1 $\beta$, TNF- $\alpha$ ) and favors the production of MMP-1, MMP-3, MMP-13, IL-6, and prostaglandin E2 [185,186]. Furthermore, in an OA experimental model, Yin and collaborators [187] demonstrated that IL-1 $\beta$ increases TRPA1 expression contributing to overload $\mathrm{Ca}^{2+}$ influx, which, in turn, causes a significant reduction of mitochondrial membrane potential, activating the intrinsic apoptotic pathway.

Several in vitro and in vivo studies provided clear evidence that excessive generation of ROS and of RNS in OA chondrocytes induces altered gene transcription and protein synthesis and that in this setting, apoptosis is activated $[120,126,188]$. For instance, in the cartilage endplate, intracellular production of $\mathrm{H}_{2} \mathrm{O}_{2}$ induced apoptosis and calcification via ERK/p38/p65 signaling pathway [189]. Moreover, $\mathrm{H}_{2} \mathrm{O}_{2}$ generated by the hypoxanthine-xanthine oxidase system causes higher levels of lipid peroxidation, cartilage ECM degradation, and apoptosis by inducing caspase activation, down- and up-regulating B-cell lymphoma 2 (Bcl-2) and Bcl-2 Associated X (Bax) expression, respectively, and suppressing Akt kinase activity [190]. Similarly, $\mathrm{H}_{2} \mathrm{O}_{2}$-treated chondrocyte apoptosis has been observed as the result of altered expression of inducible NOS (iNOS), PI3K/Akt, caspase-9, and caspase-3 protein expression levels [191] or through $\mathrm{Ca}^{2+}$ signaling due to $\mathrm{Ca}^{2+}$ release from intracellular storage and activation of caspase-3 [192], thus underlining that the heterogeneity of apoptotic signaling pathways is context-dependent.

$\mathrm{NOS}$ can form $\mathrm{NO}$ from $\mathrm{O}_{2}$ and L-arginine. There are three isoforms of NOS: two constitutive (i.e., endothelial and neuronal NOS) and one inducible (i.e., iNOS). In normal conditions, chondrocytes express low levels of iNOS, but in human OA cartilage iNOS expression is induced by different stimuli (e.g., abnormal biomechanical forces and proinflammatory cytokines) [193,194]. An increase of NO production has been observed in OA cartilage leading to enhanced MMPs activity and inhibition of proteoglycan synthesis [193]. Interestingly, $\mathrm{NO}$, in its nitrosonium form $\left(\mathrm{NO}^{+}\right)$, can bind to cysteine residues to form S-nitrosothiols, which, in turn, regulate transcription factor and enzyme activities such as NF- $\mathrm{kB}$, activator protein-1 (AP-1), p21 kinase, c-Jun N-terminal kinases (JNKs), caspase-3, and caspase-9 [195]. Whereas some studies showed that NO donors given to cultured chondrocytes caused apoptosis $[135,196]$, other published results reported that the overexpression of the iNOS gene in transfected chondrocytes did not determine cell death. Therefore, it has been suggested that NO, by itself, can be protective under certain oxidative stress conditions and that cell death occurs only when other ROS species are involved $[197,198]$. NO rapidly reacts with $\mathrm{O}_{2}{ }^{\bullet-}$ forming the free radical peroxynitrite $\left(\mathrm{ONOO}^{-}\right)$, which induces mitochondrial dysfunction in chondrocytes leading to caspaseindependent apoptosis through $\mathrm{Ca}^{2+}$-dependent protease activation (i.e., calpain) [199].

\subsection{Microribonucleic Acids and Long Non-Coding RNA in the Context of Cartilage Apoptosis}

Microribonucleic acids (miRNAs or miRs) are small nucleotide non-coding RNAs, whose principal function is to regulate gene expression at transcriptional and post-transcriptional levels binding to specific sequences of target mRNAs.

Chondrocytes express many miRNAs, which, governing hundreds of other genes, regulate cartilage development, homeostasis, and may lead to pathologic conditions [200]. Moreover, several studies have highlighted that aberrant expression of some miRNAs promotes chondrocyte apoptosis (Figure 3), and given the relationship between apoptosis and ectopic mineralization, these miRNAs may also have an effect on HA deposition.

In OA chondrocytes it has been observed a number of up-regulated miRNAs. In particular, miR-9 down-regulates monocyte chemoattractant protein-induced protein 1 expression, promoting IL-6 expression and chondrocyte apoptosis [201]; miR-103 induces cell apoptosis and suppresses cell proliferation down-regulating PI3K/AKT pathway by blocking sphingosine kinase 1 expression [202]; miR-34a promotes apoptosis by directly regulating the silent information regulator 1 (SIRT1)/p53 signaling pathway [203] or through 
the delta-like protein 1 via PI3K/AKT pathway [204]. SIRT1, in particular, is a deacetylase playing a crucial role in the prevention of apoptosis, enhancing acetylated p53 and Bax and down-regulating Bcl-2. Silencing miR-34a by locked-nucleotide-analog (LNA)-modifiedanti-sense can decrease IL- $1 \beta$-induced rat chondrocyte apoptosis, affecting collagen type II expression and iNOS activity [204]. Furthermore, as shown in in vitro (i.e., lipopolysaccharide treated chondrocytes) and in vivo (rat OA model) experiments, miR-363-3p controls apoptosis enhancing p53 and caspase-3 expression, whereas it down-regulates nuclear factor-erythroid 2-related factor 1 gene expression, which serves as a promoter of nuclear and mitochondrial interactions, modulating essential processes ranging from protein production to mitochondrial biogenesis [205]. Recently, in a rat OA model, it has been demonstrated that miR-495 enhances chondrocyte apoptosis and senescence acting through AKT1 and the AKT/mTOR signaling pathways. Moreover, up- or down-regulated expression of miR-495 stimulated or inhibited, respectively, the expression of ECM-related enzymes, such as MMP-1, MMP-13, and ADAMTS-5 [206]. Inhibiting miR-495 can suppress chondrocyte apoptosis [207].

By contrast, chondrocyte apoptosis is associated with the down-regulation of miR-29a, which favors Bax expression leading to caspase-3 activation [208].

In addition to studies disclosing the involvement of an increased number of miRs in regulating chondrocyte apoptosis (e.g., miR-10a-5p, miR-139, and miR-146) [209-211], in the last years, great attention has also been paid to long non-coding RNAs (lncRNAs), non-protein-coding transcripts characterized by a minimal length of 200 nucleotides, which govern key cellular processes (e.g., apoptosis and differentiation). It has been reported that a number of lncRNAs were involved in cartilage diseases contributing, for example, to ECM degradation, apoptosis, and osteogenic differentiation [212-215]. For instance, growth arrest-specific 5 (GAS5), an RNA gene affiliated with the lncRNA class, was upregulated in OA, acting as a negative regulator of miR-21, causing an increased expression of different MMPs (e.g., MMP-2, MMP-13, and ADAMTS-4) and favoring apoptosis [216]. Another lncRNA involved in promoting the expression of the MMP family and chondrocyte apoptosis is the HOX antisense intergenic RNA (HOTAIR), which is significantly upregulated in OA compared to normal cartilage [217]. In an in vitro OA model (i.e., IL$1 \beta$-stimulated rabbit primary chondrocytes), HOTAIR is increased, whereas HOTAIR knockdown reduces IL-1 $\beta$-induced apoptosis [218].

\section{Apoptosis and Vascular Calcification}

In vascular tissue, apoptosis of endothelial (EC) and vascular smooth muscle cells (VSMCs) represents a physiologic process that, during developmental stages, allows programmed capillary regression [219] and ductus arteriosus formation [220], and, during the postnatal period, regulates blood vessels' remodeling [221]. However, apoptosis also plays a key role in many vascular and vascular-related diseases (e.g., atherosclerosis and hypertension) and can significantly contribute to vascular calcification (VC) [222-224]. In vitro studies have demonstrated that homocysteine, a known predictive factor of vascular diseases, can induce endothelial cell apoptosis through increased generation of reactive oxygen species. Moreover, homocysteine can promote vascular calcification by increasing lipid peroxidation. In the light of these data, it was suggested that lowering plasma homocysteine levels can ameliorate endothelial homeostasis and vascular calcification [225].

$\mathrm{VC}$ is a typical and life-threatening complication observed in many diseases, including atherosclerosis, diabetes, coronary artery disease, and end-stage renal disease under the influence of inflammatory cytokines and growth factors [226]. It is characterized by the pathological deposition of minerals (e.g., HA) in vessel walls and in cardiac and vascular valves, thus altering tissue architecture and function as well as cell behavior [14]. Moreover, calcification is typically associated with a VSMC shift from a contractile to an osteogenic phenotype, contributing to altering the local balance between pro- and anti-calcifying factors and favoring the release of matrix vesicles [227]. The phenotypic transition of VSMCs is characterized by a down-regulation of smooth muscle 22- $\alpha$ protein, alpha-smooth 
muscle actin, and smooth muscle myosin heavy chain, whereas calcification and osteoblast markers, including the osteoblast-promoting factor Runx2, Msx2, ALP, collagen type I, OPN, MMP-2, and PiT-1, are up-regulated [227]. In particular, the activation of PiT-1 increases the intracellular levels of Pi that, in turn, regulates intracellular signaling pathways, such as the Wnt/ $\beta$-catenin and Axl/growth arrest-specific gene 6 pathways, leading to VC. Despite the similarities between vascular and bone mineralization, it has to be pointed out that, besides the pathologic vs. physiologic consequences, VC is characterized by localized mineralized areas of the elastic component, whereas collagen is rarely involved. Moreover, calcifying VSMCs exhibit reduced viability with increased apoptosis and higher expression of calcification markers (e.g., TNAP or Runx2) although at lower levels compared to bone cells [228].

Calcification increases vessel stiffness and has consequences on hemodynamic properties and on mechanical vascular wall stress. Cyclic stretching of VSMCs further stimulates phenotype switching and adversely affects endothelial function determining impaired NO synthesis, up-regulation of pro-inflammatory and pro-atherogenic factors, increased oxidative stress [227]. To be noted that endothelial dysfunction rests on the repair potential of endothelial progenitor cells and on the ability of these cells to promote the repair of the luminal lining or to acquire a pro-osteogenic phenotype, thus actively contributing to VC [48].

Whereas the arterial intima calcification is generally related to atherosclerotic plaques and ischemic vessel injury, calcification in the vascular media is a frequent end-stage pathological change of chronic diseases [229]. In blood vessels, mineral deposition is mainly localized in necrotic areas within the atherosclerotic plaque or within the elastic lamellae, which are layered between the syncytia of smooth muscle cells. Elastic fibers are primarily composed of elastin molecules assembled with a number of matrix components (i.e., fibrillins, fibulins, glycosaminoglycans/proteoglycans, glycoproteins, lysyl oxidase, lipids as well as calcium-binding proteins), whose amounts and ratios change depending on tissues' functional requirements, age, and pathologic conditions [14]. Therefore, calcification causes decreased elasticity of vessels and valves and hamper tissue mechanics and blood flow, possibly resulting in heart attack and stroke [230]. ECM organization (e.g., stiffness, porosity, and density) controls cellular differentiation and regulates calcification under the influence of matrix components as collagens [231]. For instance, collagen type I has been shown to promote VSMCs phenotypic differentiation into osteoblast-like cells and, in the course of atherosclerosis, there is an increased amount of collagen type I. Similarly to bones, increased collagen type I content favors HA deposition in the arterial wall, whereas collagen type IV inhibits mineralization [232].

Many reports have highlighted the importance of cell-matrix interactions in transducing signals from the extracellular environment to the nucleus and vice versa; therefore, qualitative and quantitative changes in matrix components modulate cell morphology and behavior [233]. Interestingly, it has been demonstrated in EC, VSMCs, and fibroblasts that mechanical stress (both in the form of cyclic stretch and tensile strain) can modulate the expression of calcification-related genes by up-regulating pro-osteogenic factors such as Sprouty-1, BMP-2, periostin and down-regulating calcification inhibitors as osteopontin and thrombospondin [234]. ECs, in particular, through the endothelial to mesenchymal transition (EndMT), seem to play a key role in initiating VC in the tunica intima through the release of BMP-2 and activation of the $\mathrm{Wnt} / \beta$-catenin pathway, losing their specific markers (i.e., CD31 and VE-cadherin) and becoming more responsive to BMP/TGF- $\beta$ signaling pathways [235]. Furthermore, ECs release miRNAs capable of switching VSMCs towards a procalcific phenotype in the tunica media [235]. In vascular tissues, cell plasticity is actively modulated by mechanical stretching that also induces VSMC proliferation as well as migration, apoptosis, phenotypic switching, and vascular remodeling [236]. In these conditions, magnesium can enter VSMCs through the transient receptor potential melastatin 7 channel in response to the up-regulated expression of angiotensin II type I receptor (AT1-R). Since 
insufficient magnesium has been associated with $\mathrm{VC}$, magnesium levels could be regulated by angiotensin II, thus preventing phosphate-induced calcification [237].

VC is generally associated with age-related diseases, and in vitro aging models have demonstrated an increased susceptibility of cells to pro-osteogenic signals, but recent evidence indicates that the relationship between aging and calcification is likely multifactorial [238]. For instance, senescent VSMCs are characterized by the release of a high number of extracellular vesicles, up-regulation of Runx-2 and TNAP, altered redox balance, mitochondrial dysfunction, and inhibition of Sirtuin-1 with corresponding up-regulation of p53 [238].

To further highlight the complexity of pro-osteogenic signaling mechanisms in vascular tissues, it is worth mentioning the post-transcriptionally regulatory activities exerted by non-coding RNAs as those stored within exosomes [239].

By microarray analysis, during the progression of vascular calcification, it was observed an increased expression of miR-125b, miR-30a, and miR-32 and a decreased expression of miR-29a, miR-210, and miR-320 [240].

For instance, gain- and loss-of-function studies demonstrated that miR-32 up-regulates the expression of BMP-2, RUNX2, OPN, and matrix GLA protein through the PI3K signaling pathway. Consistently, high circulating levels of miR-32 were detected in patients with coronary artery disease (CAD) with calcification compared to patients with CAD in the absence of calcification [240].

The demonstration that in areas of mineral deposition matrix vesicle-like structures can be observed containing high levels of Bax provided evidence that these structures can represent remnants of apoptotic cells [241]. During VC, both ABs and MVs derived from VSMCs promote the accumulation of calcium-phosphate in a microenvironment favoring mineralization. The observation that apoptosis takes place prior to the onset of calcification put forward the hypothesis that apoptosis is a key initiating process for VC [242].

Within this context, oxidative stress up-regulates the expression of RUNX2, leading to the osteogenic conversion of VSMCs. Consistently, Runx2 induces the expression of matrix proteins such as collagen type I, osteocalcin (OC), OPN, bone sialoprotein, and TNAP activity $[106,107]$. Moreover, mitochondrial ROS promote the expression of tristetraprolin, a RNA destabilizing factor, that reduces the expression of ANKH, an inhibitor of calcification [93].

There are several data indicating that $\mathrm{VC}$ is also associated with endoplasmic reticulum stress (ERS)-induced apoptosis and altered calcium homeostasis since the endoplasmic reticulum is the primary site for $\mathrm{Ca}^{2+}$ storage [243].

Moreover, in diabetic patients, high glucose interferes with ER function, and ERS generates several pro-apoptotic signals and favors the phenotype transition of VSMCs [244]. Within this context, the antidiabetic drug metformin may counteract vascular calcification reducing osteogenic markers expression (e.g., Runx2 and BMP-2) [245], restoring mitochondrial biogenesis and inhibiting $\beta$-glycerophosphate-induced pyruvate dehydrogenase kinase expression, a mitochondrial metabolic regulator associated with mitochondrial dysfunction in calcified VSMCs [246].

Interestingly, it has been recently demonstrated that $\mathrm{VC}$ can be reduced by globular adiponectin, a bioactive polypeptide secreted by adipose cells, which negatively correlates with the degree of coronary artery calcification and protects vasculature by inducing $\mathrm{NO}$ activation, promoting the expression of osteoprotegerin (OPG) and the repair of EC, while inhibiting the phenotype conversion of VSMC into osteoblast-like cells [247]. These findings may open new perspectives for the treatment of VC in diabetic patients, aiming to reduce cardiovascular complications.

Several studies have shown major sites of VC in atherosclerotic plaques. Atherosclerosis is a pathologic condition characterized by progressive accumulation of lipoproteins within the vessel wall, development of an inflammatory response that alters tissue architecture, and causes reduced blood flow and blood supply to organs. It is one of the leading risk factors for cardiovascular diseases, especially in Western Countries, being detected in 
$100 \%$ of individuals $>65$ years of age [248]. It is now well recognized that in atherosclerosis, there are many types of cell death, including necrosis, apoptosis, and autophagy [223]. In the course of the atherosclerotic process, apoptotic cells are few in early plaques, whereas they increase with the evolution of the lesions. Remnants of apoptotic VSMCs remain in the plaque as membrane vesicles and can act as nucleating structures for plaque microcalcifications and enhanced plaque progression. VC is further promoted by mechanical injury, high levels of NO, oxidized low-density lipoproteins (oxLDL), and pro-inflammatory cytokines (e.g., TNF- $\alpha$ by macrophages and IFN- $\gamma$ by T lymphocytes) [249].

Pro-inflammatory cytokines, as TNF- $\alpha$ and ILs, are involved in diabetic patients and in diabetes associated VC [250]. In particular, TNF- $\alpha$ favors calcium deposition by VSMCs, up-regulation of BMP, expression of ALP through NF- $\mathrm{k} \beta$ pathway as well as the Msx2-Wnt osteogenic program [251].

By contrast, IL-24 down-regulates calcification and osteoblast markers including Runx2, ALP, OPN, BMP-2, and the Wnt / $\beta$-catenin pathway and, therefore, can efficiently attenuate $\beta$-glycerophosphate-induced VSMC calcification, decreasing either Bax/Bcl-2 expression ratio and apoptosis [252].

Similarly, OPG exerts anti-atherosclerotic and anti-calcification effects in in vitro and in animal models [253], although the role of OPG may be context-dependent since it was observed increased in serum of patients with VC [17].

\subsection{Changes in Matrix Components in the Context of Vascular Apoptosis}

Survival of anchorage-dependent cells such as EC [254] and VSMC [255] are secured by cell-to-cell and cell-to-matrix contacts, as demonstrated in in vivo models, where up-regulation of the integrin $\alpha_{\mathrm{v}} \beta_{3}$ counteracts cell-death pathways by inhibiting p53 activity, decreasing p21 and Bax expression and activating NF- $\mathrm{kB}$ [256]. By contrast, downregulation or truncation of vascular endothelial (VE)-cadherins induces EC apoptosis and abolishes signals by VEGF-A to Akt kinase and Bcl-2 $[257,258]$. In vitro studies on VSMC cultured within collagen gels have demonstrated that interactions of these cells with tenascin-C through $\alpha_{\mathrm{v}} \beta_{3}$ integrins can change cell shape and epidermal growth factor (EGF)-dependent growth by inducing a clustering of the EGF-receptors and may rescue VSMC from apoptosis [259]. Moreover, exposure of human EC to TNF- $\alpha$ and IFN- $\gamma$ results in suppression of $\mathrm{EC} \alpha_{\mathrm{V}} \beta_{3}$ activity leading to decreased cell adhesion and survival [260].

Furthermore, the observation that interfering with $\beta 1$ integrins can modulate the effect of TGF- $\beta 1$, and Bcl-2 protein expression highlights the importance of the microenvironment and of cell-matrix interactions on apoptotic signaling pathways [261]. It has been demonstrated that through $\beta_{1}$ integrins, TGF- $\beta_{1}$ exerts context-dependent bifunctional effects; being an inducer of endothelial cell apoptosis, whereas it prevents VSMC death. In particular, in endothelial cells, TGF- $\beta_{1}$ stimulation results in decreased Bcl-2 protein levels. Interestingly, the pro-apoptotic effect of TGF- $\beta_{1}$ on HUVEC (human umbilical vein endothelial cells) can be counteracted by activation of $\beta_{1}$ integrins and increased expression of the anti-apoptotic factor Bcl-2 [261].

Moreover, it has been demonstrated that p53 suppression can be induced by extracellular matrix survival signals as those generated by fibronectin through the focal adhesion kinase (FAK), whose phosphorylation leads to p53 inactivation and maintenance of cell survival [262,263]. Furthermore, nonfibrillar or monomeric collagens allow VSMCs to undergo proliferation in response to mitogens in culture, while fibrillar collagens inhibit cell proliferation by up-regulating specific inhibitors of the cell cycle [264]. Therefore, the ECM determines whether cells remain quiescent, survive, or multiply in response to growth factors [248].

In EC apoptosis, it has been demonstrated that caspase-mediated degradation represents an early event leading to the intracellular cleavage of FAK, $\beta$-catenin, and plakoglobin and to the shedding of VE-cadherin, and therefore disruption of extracellular survival signals [265]. Interestingly, a link between mechanical stimulation and cell survival or death has been suggested by several groups. Indeed, HUVEC cultured under static conditions 
undergo a basal level of apoptosis, whereas in vitro or in vivo exposure of cells to flow inhibits the apoptotic process [266,267]. These effects involve the shear-induced phosphorylation of Akt/PKB pathway, phosphorylation of the endothelial NO synthase, production of NO that, in turn, inhibits caspase-3 activation and prevents EC apoptosis [268-270]. Interestingly, shear stress-dependent up-regulation of $\mathrm{Cu} / \mathrm{Zn}$ SOD and NO synthase can prevent caspase activation upon a number of apoptotic stimuli (e.g., oxygen free radicals, oxLDL, or TNF- $\alpha$ ) [271,272].

Since caspases play an essential role in apoptosis, inhibition of these proteases has been investigated as an approach to reduce apoptotic cell death and to stabilize atherosclerotic plaques, as suggested by treating VSMC with the caspase inhibitor zVAD-fmk [73].

In addition to caspases, atherosclerotic plaques are characterized by overexpression of MMPs, which contribute to matrix degradation, cell detachment, and induction of cell death [273]. MMPs could also modulate apoptosis by cleaving death ligands (e.g., TNF- $\alpha$ and Fas-L) and their receptors, which trigger apoptosis by acting in an autocrine or paracrine manner [274]. For instance, MMP-1, $-2,-8,-9,-13$ and the MT-MMPs, MMPs 14-17 can all cleave pro-TNF- $\alpha$, although only ADAM-17/TNF- $\alpha$ converting enzyme (TACE) and, with a lesser specificity, MMP-7 produce the correctly processed soluble form of TNF- $\alpha$ [275].

\subsection{Death Receptors, Cytokines and Growth Factors in the Context of Vascular Apoptosis}

Apoptosis of vascular cells is observed in vivo in normal vessel development and in a number of vascular pathologies. Cell death in atherosclerosis has been firstly reported by Virchow during a lecture given at the University of Berlin in 1858, although, at that time, the term cell death was used to indicate necrosis, a process closely related to chronic inflammation. The observation that cell death in VSMC is due to deregulated expression of c-myc and that this process can be reversed by expression of Bcl-2 or by other survival factors such as insulin growth factor (IGF)-1 and platelet-derived growth factor (PDGF) provided the demonstration that programmed cell death may occur in atherosclerosis [276]. It is now well recognized that in atherosclerosis, there are many types of cell death: necrosis, apoptosis, and autophagy [223].

Increased EC apoptosis has been observed in the early phases of atherosclerosis, whereas apoptosis of VSMCs and of macrophages is typically localized in 'vulnerable' lesions, which are more prone to rupture. VSMC apoptosis promotes plaque thrombogenicity by exposing phosphatidylserine on the surface of apoptotic cells that can act as a substrate for thrombin generation and activation of the coagulation cascade.

In agreement with these observations, the death receptor Fas is expressed throughout the vessel wall, and the Fas receptor/Fas-L pathway, which is involved in cell apoptosis, has been widely recognized in vascular diseases [277].

Interestingly, monocyte/macrophages induce human VSMC apoptosis through Fas$\mathrm{L} / \mathrm{Fas}, \mathrm{NO}$, and TNF- $\alpha$ also acting in synergy with inflammatory cytokines as IL-1 $\beta$ and IFN- $\gamma[278,279]$. Whereas TNF- $\alpha$ up-regulates macrophage iNOS and surface Fas-L through autocrine regulation of TNF-R1 and TNF-R2, Fas and TNF-R1 initiate caspase-dependent death signaling by similar mechanisms. Interestingly, although TNF inhibition hinders Fas$\mathrm{L}$, the opposite is not true since Fas-L inhibition does not hamper TNF- $\alpha$ surface expression, indicating that Fas-L is downstream of TNF- $\alpha$. In contrast, NO and TNF- $\alpha$ appear to be mutually dependent because inhibiting NO reduces TNF- $\alpha$ and vice versa [278].

Lindner and co-workers [280] demonstrated that preactivated peripheral blood mononuclear monocytes could induce EC apoptosis through a mechanism that is, at least in part, dependent on TNF- $\alpha$, since it can be efficiently inhibited by anti-TNF- $\alpha$ monoclonal antibodies or by treatment with IL-10, an anti-inflammatory cytokine with anti-apoptotic activity. It has to be mentioned that TNF- $\alpha$, similarly to other inflammatory cytokines, induces the Bcl-2 homolog human A1, but can also activate the NF- $\mathrm{B}$ pathway, thus indicating that TNF- $\alpha$ can initiate both pro-apoptotic and anti-apoptotic pathways in a context-dependent mode $[281,282]$. 
In the course of endothelial inflammation, it is worth mentioning that the antiapoptotic proteins Bcl-2 and Bcl-XL are able to down-regulate EC activation through NF- $\mathrm{BB}$ inhibition. Bcl-2 and Bcl-XL may, therefore, be cytoprotective, counteracting both pro-apoptotic and pro-inflammatory stimuli [283].

Tumour necrosis factor-related apoptosis-inducing ligand (TRAIL), a member of the TNF protein superfamily, induces apoptosis, binding to death signaling receptors DR4 and DR5 [284]. Although it was suggested that TRAIL-induced apoptosis is typically triggered in transformed cells, a number of studies provided evidence that TRAIL is highly expressed in atherosclerotic lesions involving endothelial and smooth muscle cells [285]. These events may accelerate the switch of a stable plaque to a rupture-prone plaque [286]. Interestingly, TRAIL-induced apoptosis can be inhibited by OPG, a soluble decoy receptor also acting as regulator of osteoclastogenesis preventing RANKL-RANK binding and bone resorption [287].

Among growth factors, fibroblast growth factor 21 (FGF21) is considered a mitokine exerting several metabolic functions possibly regulating autophagy and cell death processes [288]. Moreover, it has been demonstrated that FGF21 can ameliorate atherosclerosis inhibiting C/EBP homologous protein (CHOP) and caspase-12 signaling pathways associated with ERS-mediated apoptosis [289,290]. CHOP is a transcription factor that regulates the expression of numerous pro-apoptotic proteins leading to oxidative stress and apoptosis, is also up-regulated in calcified aortas [289]. Caspase-12 is a cysteine protease that is specifically activated by ERS, and subsequently, it activates caspase-9, caspase-3, and apoptosis, and is involved in VC [291]. The observation that both CHOP expression and caspase-12 can be significantly reduced by FGF21 further demonstrates that the growth factor may reduce ERS, apoptosis, and VC [289,292].

\subsection{Mitochondria and Reactive Oxygen and Nitrogen Species in the Context of Vascular Apoptosis}

Calcified blood vessels are associated with mitochondrial damage and dysfunction, mainly affecting the mitochondrial electron transport chain and, consequently, ROS production that, in turn, regulates cell proliferation, apoptosis, and $\mathrm{Ca}^{2+}$ storage [75]. Mitochondrial dysfunction or abnormalities lead to the loss of mitochondrial membrane potential, enhanced intracellular ROS generation, $\mathrm{Ca}^{2+}$ overload, and decreased ATP synthesis. Moreover, mitochondria accumulate calcium in an energy-dependent manner, and excessive intake of $\mathrm{Ca}^{2+}$ by mitochondria triggers the opening of permeability switching pores and the release of cytochrome $c$ into the matrix, which led to apoptosis and to VC [75].

Atherosclerotic plaques develop as a consequence of the accumulation of circulating lipids and the subsequent migration of inflammatory cells. This process is markedly enhanced by oxLDL that have been shown to exert cytotoxic effects on cultured EC. In vitro studies have demonstrated increased apoptotic cell death of aortic EC exposed to cholesterol oxides or to oxLDL [293]. OxLDL promotes apoptosis through the Fas signaling pathway [294], down-regulating Bcl-2 and activating caspase-3 [295], but cell death can be prevented by chelating extracellular calcium or by inhibiting calcium influx, indicating that increase of cytosolic calcium precedes apoptotic events [296].

In VSMC, the pro-apoptotic effects of pro-inflammatory cytokines (TNF- $\alpha$, IFN- $\gamma$, and IL-1) are also associated with high production of NO via iNOS [297]. This process is mediated by TNF $\alpha$ and FasL interactions with their receptors [298]. By contrast, the anti-inflammatory cytokine IL-10 is associated with decreased levels of iNOS expression and apoptotic cell death [299]. These findings suggest that apoptosis results from an excessive inflammatory reaction. Moreover, in VSMCs, NO-induced apoptosis is prevented by inhibiting the cGMP-dependent protein kinase I $\alpha$, or by adding angiotensin II [300]. It is noteworthy that NO, at physiological concentrations, acts as an anti-apoptotic factor, whereas it exerts a pro-apoptotic effect at high levels (e.g., during inflammatory response) [301,302]. Similarly, angiotensin II may have dual effects on VSMC apoptosis, preventing or promoting apoptosis through angiotensin II type 1 or type 2 receptor stimulation, respectively [303]. 


\subsection{Microribonucleic Acids and Long Non-Coding RNA in the Context of Vascular Apoptosis}

Several miRs have been reported to control VSMC turnover and apoptosis targeting growth factor pathway intermediates, ROS production, transcription factors, cell cycle, and/or apoptosis control points. For instance, miR-21, miR-26a, miR-29b, and miR-126 have been described in VSMC as regulators of the ratio between apoptosis and proliferation, whereas miR-143 and miR-145 modulate the growth process by phenotype changes [304].

Furthermore, miR-25 can inhibit corticosterone-induced VSMC apoptosis by targeting the pro-apoptotic protein MOAP1 and possibly also the p70S6k pathway [305]. MOAP1 promotes caspase-dependent apoptosis by binding pro-apoptotic BAX via its Bcl-2 homology3- (BH3-) like domain, and it is up-regulated upon several apoptotic stimuli [306]. Since MOAP is a direct target for miR-25, it has been suggested that miR-25-dependent downregulation of MOAP1 may represent a key mechanism in apoptosis inhibition with positive effects on atherogenesis and eventually on calcification [305]. It has to be further investigated if these data may also be relevant for therapeutic implications in humans.

miR-148b has been reported as an inhibitor of atherosclerosis by decreasing VSMC proliferation and migration, and increasing apoptosis [307].

Interestingly, in addition to $\mathrm{miR}$, recent studies in calcified vessels and valves provided evidence that lncRNAs (HOTAIR, H19, TUG1, and ES3) regulate a number of signaling pathways, such as Wnt/ $\beta$ catenin and NOTCH, or target specific miR (e.g., miR-34c, miR125 , miR-204, and miR483). For instance, the taurine up-regulated gene 1 (TUG1) is a functional lncRNA promoting macrophage's growth and the atherosclerotic inflammatory response regulating the expression of miR-133a that, in turn, modulates VSMC proliferation and endothelial cell apoptosis [308]. Moreover, TUG1 is overexpressed when cells are exposed to oxLDL and can increase IGF2 expression by competitively sponging miR148b. Therefore, it has been suggested that TUG1 regulates proliferation and apoptosis of VSMC and HUVEC by miR-148b/IGF2 axis, thus providing a novel patho-mechanism for atherosclerosis [309].

Apoptosis in EC is suppressed by lncRNA HOTAIR, and these effects may contribute to control cell proliferation and migration in the course of atherosclerosis [310].

\section{Conclusions}

In summary, aberrant mineralization of soft connective tissues is a complex multifactorial process modulated either at pre- and post-transcriptional levels, and it has been observed to progressively increase its frequency due to longer life expectancy and to the higher incidence of chronic degenerative diseases. Ectopic calcification negatively affects the quality of life of aged patients and is responsible for severe complications, mainly affecting joints and the cardiovascular system. In most cases, extra-skeletal mineralization has been observed to be the consequence of apoptotic cell death or at least to intersect some apoptotic signaling pathways. Therefore, apoptosis plays an active role in the calcification process, and ABs may serve as nucleation sites for the crystal deposition as observed in cartilage and in vascular mineralization. Moreover, numerous studies, performed both in vitro and in vivo, have highlighted as extraosseous calcification shows similarities to physiological skeletal mineralization. However, factors regulating apoptosis and/or calcification exert multiple effects dependent, for instance, on cell type, on cell-cell and on cell-matrix interactions, on extracellular matrix composition, and on mechanical forces. The frequent occurrence of dual effects is, therefore, cell and context-dependent, as clearly shown in the two models we have analyzed in the present review (i.e., chondrocytes in the cartilage tissue and EC and VSMC in vascular tissue).

At present, there are a number of drugs (e.g., metformin, statins, bisphosphonates, and anti-oxidants) which may exert their effects interfering with cell fate and which have also been associated with hydroxyapatite deposition; however, therapeutic approaches capable of inhibiting ectopic calcification without negatively interfering on the whole mineralization process are in their infancy. Therefore, better exploring the relationships 
between apoptosis and hydroxyapatite deposition will be highly relevant to identify new and more effective therapeutic treatments against extraosseous calcification.

Author Contributions: Conceptualization, F.B.; data curation, F.B., F.D.L.; Writing-Original draft preparation, F.B., F.D.L.; Writing-Review and editing, D.Q. All authors have read and agreed to the published version of the manuscript.

Funding: Authors are grateful to PXE ITALIA Odv for supporting the research on pathologic calcification (E96C18000600007) (D.Q.).

Institutional Review Board Statement: Not applicable.

Informed Consent Statement: Not applicable.

Data Availability Statement: Not applicable.

Acknowledgments: Figures 1 and 3 were created with Biorender.com.

Conflicts of Interest: The authors declare no conflict of interest.

\section{References}

1. Elmore, S. Apoptosis: A Review of Programmed Cell Death. Toxicol. Pathol. 2007, 35, 495-516. [CrossRef] [PubMed]

2. Kim, K.M. Apoptosis and Calcification. Scanning Microsc. 1995, 9, 1137-1175. [PubMed]

3. Sharma, H.P.; Jain, P.; Amit, P.; Sinha, A. Apoptosis (Programmed Cell Death)—A review. World J. Pharm. Res. $2014,3,1854-1872$.

4. Fuchs, Y.; Steller, H. Live to Die another Way: Modes of Programmed Cell Death and the Signals Emanating from Dying Cells. Nat. Rev. Mol. Cell Biol. 2015, 16, 329-344. [CrossRef] [PubMed]

5. Tang, H.L.; Tang, H.M.; Fung, M.C.; Hardwick, J.M. In Vivo CaspaseTracker Biosensor System for Detecting Anastasis and Non-Apoptotic Caspase Activity. Sci. Rep. 2015, 5, 9015. [CrossRef] [PubMed]

6. Zakharov, I.I.; Savitskaya, M.A.; Onishchenko, G.E. The Problem of Apoptotic Processes Reversibility. Biochem. Mosc. 2020, 85, 1145-1158. [CrossRef] [PubMed]

7. Hunziker, E.B. Cartilage Histomorphometry. Methods Mol. Med. 2007, 135, 147-166. [CrossRef]

8. Clarke, B. Normal Bone Anatomy and Physiology. Clin. J. Am. Soc. Nephrol. 2008, 3, S131-S139. [CrossRef]

9. Li, Q.; Uitto, J. Mineralization/Anti-Mineralization Networks in the Skin and Vascular Connective Tissues. Am. J. Pathol. 2013, 183, 10-18. [CrossRef]

10. Boraldi, F.; Lofaro, F.D.; Costa, S.; Moscarelli, P.; Quaglino, D. Rare Co-Occurrence of Beta-Thalassemia and Pseudoxanthoma Elasticum: Novel Biomolecular Findings. Front. Med. 2020, 6, 322. [CrossRef]

11. Giachelli, C.M. Ectopic Calcification: Gathering Hard Facts about Soft Tissue Mineralization. Am. J. Pathol. 1999, 154, 671-675. [CrossRef]

12. Mackey, R.H.; Venkitachalam, L.; Sutton-Tyrrell, K. Calcifications, Arterial Stiffness and Atherosclerosis. Atheroscler. Large Arter. Cardiovasc. Risk 2007, 44, 234-244. [CrossRef]

13. Li, Q.; Jiang, Q.; Uitto, J. Ectopic Mineralization Disorders of the Extracellular Matrix of Connective Tissue: Molecular Genetics and Pathomechanisms of Aberrant Calcification. Matrix Biol. 2014, 33, 23-28. [CrossRef] [PubMed]

14. Quaglino, D.; Boraldi, F.; Lofaro, F.D. The Biology of Vascular Calcification. Int. Rev. Cell Mol. Biol. 2020, 354, 261-353. [CrossRef]

15. Kirsch, T. Biomineralization-An Active or Passive Process? Connect. Tissue Res. 2012, 53, 438-445. [CrossRef]

16. Kirsch, T. Determinants of Pathological Mineralization. Curr. Opin. Rheumatol. 2006, 18, 174-180. [CrossRef]

17. Bäck, M.; Aranyi, T.; Cancela, M.L.; Carracedo, M.; Conceição, N.; Leftheriotis, G.; Macrae, V.; Martin, L.; Nitschke, Y.; Pasch, A.; et al. Endogenous Calcification Inhibitors in the Prevention of Vascular Calcification: A Consensus Statement From the COST Action EuroSoftCalcNet. Front. Cardiovas. Med. 2018, 5. [CrossRef]

18. Black, A.; Kanat, I. A Review of Soft Tissue Calcifications. J. Foot Surg. 1985, 24, 243-250.

19. Meyers, C.; Lisiecki, J.; Miller, S.; Levin, A.; Fayad, L.; Ding, C.; Sono, T.; McCarthy, E.; Levi, B.; James, A.W. Heterotopic Ossification: A Comprehensive Review. JBMR Plus 2019, 3. [CrossRef]

20. Seethapathy, H.; Noureddine, L. Calciphylaxis: Approach to Diagnosis and Management. Adv. Chronic Kidney Dis. 2019, 26, 484-490. [CrossRef]

21. Kim, K.M.; Trump, B.F. Amorphous Calcium Precipitations in Human Aortic Valve. Calcfied Tissue Res. 1975, 18, 155-160. [CrossRef] [PubMed]

22. Michotte, Y.; Smeyers-Verbeke, J.; Ebinger, G.; Maurus, R.; Pelsmaekers, J.; Lowenthal, A.; Massart, D.L. Brain Calcification in a Case of Acute Lymphoblastic Leukaemia. J. Neurol. Sci. 1975, 25, 145-152. [CrossRef]

23. Prieto, R.M.; Gomila, I.; Söhnel, O.; Costa-Bauza, A.; Bonnin, O.; Grases, F. Study on the Structure and Composition of Aortic Valve Calcific Deposits. Etiological Aspects. JBPC 2011, 02, 19-25. [CrossRef]

24. Mikroulis, D.; Mavrilas, D.; Kapolos, J.; Koutsoukos, P.G.; Lolas, C. Physicochemical and Microscopical Study of Calcific Deposits from Natural and Bioprosthetic Heart Valves. Comparison and Implications for Mineralization Mechanism. J. Mater. Sci. Mater. Med. 2002, 13, 885-889. [CrossRef] 
25. Evan, A.P.; Coe, F.L.; Lingeman, J.E.; Worcester, E. Insights on the Pathology of Kidney Stone Formation. Urol. Res. 2005, 33, 383-389. [CrossRef]

26. Riley, G.P.; Harrall, R.L.; Constant, C.R.; Cawston, T.E.; Hazleman, B.L. Prevalence and Possible Pathological Significance of Calcium Phosphate Salt Accumulation in Tendon Matrix Degeneration. Ann. Rheum. Dis. 1996, 55, 109-115. [CrossRef]

27. Ivanovski, O.; Drüeke, T.B. A New Era in the Treatment of Calcium Oxalate Stones? Kidney Int. 2013, 83, 998-1000. [CrossRef]

28. Perrotta, I.; Perri, E. Ultrastructural, Elemental and Mineralogical Analysis of Vascular Calcification in Atherosclerosis. Microsc. Microanal. 2017, 23, 1030-1039. [CrossRef]

29. Yang, B.Y.; Sartoris, D.J.; Resnick, D.; Clopton, P. Calcium Pyrophosphate Dihydrate Crystal Deposition Disease: Frequency of Tendon Calcification about the Knee. J. Rheumatol. 1996, 23, 883-888.

30. Fuerst, M.; Bertrand, J.; Lammers, L.; Dreier, R.; Echtermeyer, F.; Nitschke, Y.; Rutsch, F.; Schäfer, F.K.W.; Niggemeyer, O.; Steinhagen, J.; et al. Calcification of Articular Cartilage in Human Osteoarthritis. Arthritis Rheum. 2009, 60, 2694-2703. [CrossRef]

31. Ryu, K.; Iriuchishima, T.; Oshida, M.; Kato, Y.; Saito, A.; Imada, M.; Aizawa, S.; Tokuhashi, Y.; Ryu, J. The Prevalence of and Factors Related to Calcium Pyrophosphate Dihydrate Crystal Deposition in the Knee Joint. Osteoarthr. Cartil. 2014, 22, 975-979. [CrossRef] [PubMed]

32. Tanikawa, H.; Ogawa, R.; Okuma, K.; Harato, K.; Niki, Y.; Kobayashi, S.; Nagura, T. Detection of Calcium Pyrophosphate Dihydrate Crystals in Knee Meniscus by Dual-Energy Computed Tomography. J. Orthop. Surg. Res. 2018, 13, 73. [CrossRef] [PubMed]

33. Yasui, M.; Yase, Y.; Kihira, T.; Adachi, K.; Suzuki, Y. Magnesium and Calcium Contents in CNS Tissues of Amyotrophic Lateral Sclerosis Patients from the Kii Peninsula, Japan. Eur. Neurol. 1992, 32, 95-98. [CrossRef] [PubMed]

34. Garcia, G.M.; McCord, G.C.; Kumar, R. Hydroxyapatite Crystal Deposition Disease. Semin. Musculoskelet. Radiol. 2003, 7, 187-193. [CrossRef] [PubMed]

35. Boraldi, F.; Tonelli, M.; Gheduzzi, D.; Ronchetti, I.P.; Quaglino, D. Identification of Mineralized Elastic Fibers on Wet Samples by SEM. Microsc. Res. Tech. 2005, 67, 296-299. [CrossRef] [PubMed]

36. Bertazzo, S.; Gentleman, E.; Cloyd, K.L.; Chester, A.H.; Yacoub, M.H.; Stevens, M.M. Nano-Analytical Electron Microscopy Reveals Fundamental Insights into Human Cardiovascular Tissue Calcification. Nat. Mater. 2013, 12, 576-583. [CrossRef] [PubMed]

37. Coe, F.L.; Worcester, E.M.; Evan, A.P. Idiopathic Hypercalciuria and Formation of Calcium Renal Stones. Nat. Rev. Nephrol. 2016, 12, 519-533. [CrossRef]

38. Sammel, L.M.; Claus, J.R. Calcium Chloride and Tricalcium Phosphate Effects on the Pink Color Defect in Cooked Ground and Intact Turkey Breast. Meat Sci. 2007, 77, 492-498. [CrossRef]

39. McCarty, D.J. Crystals and Arthritis. Disease-a-Month 1994, 40, 258-299. [CrossRef]

40. Delogne, C.; Lawford, P.V.; Habesch, S.M.; Carolan, V.A. Characterization of the Calcification of Cardiac Valve Bioprostheses by Environmental Scanning Electron Microscopy and Vibrational Spectroscopy. J. Microsc. 2007, 228, 62-77. [CrossRef]

41. Burstein, L.S.; Boskey, A.L.; Tannenbaum, P.J.; Posner, A.S.; Mandel, I.D. The Crystal Chemistry of Submandibular and Parotid Salivary Gland Stones. J. Oral. Pathol. Med. 1979, 8, 284-291. [CrossRef] [PubMed]

42. Ali, S.Y. Apatite-Type Crystal Deposition in Arthritic Cartilage. Scan. Electron. Microsc. 1985, 4, $1555-1566$.

43. Reid, J.D.; Andersen, M.E. Medial Calcification (Whitlockite) in the Aorta. Atherosclerosis 1993, 101, 213-224. [CrossRef]

44. Lagier, R.; Baud, C.A. Magnesium Whitlockite, a Calcium Phosphate Crystal of Special Interest in Pathology. Pathol. Res. Pract. 2003, 199, 329-335. [CrossRef]

45. Kodaka, T.; Hirayama, A.; Sano, T.; Debari, K.; Mayahara, M.; Nakamura, M. Fine Structure and Mineral Components of Primary Calculi in Some Human Prostates. J. Electron. Microsc. 2008, 57, 133-141. [CrossRef]

46. Scott, R.; Kendall, C.; Stone, N.; Rogers, K. Elemental vs. Phase Composition of Breast Calcifications. Sci. Rep. 2017, 7, 136. [CrossRef]

47. Karwowski, W.; Naumnik, B.; Szczepański, M.; Myśliwiec, M. The Mechanism of Vascular Calcification-A Systematic Review. Med. Sci. Monit. 2012, 18, RA1-RA11. [CrossRef]

48. Boraldi, F.; Bartolomeo, A.; De Biasi, S.; Orlando, S.; Costa, S.; Cossarizza, A.; Quaglino, D. Innovative Flow Cytometry Allows Accurate Identification of Rare Circulating Cells Involved in Endothelial Dysfunction. PLoS ONE 2016, 11, e0160153. [CrossRef]

49. Shira, G.; Ziegler, S.; Gahl, W.; Ferreira, C. Disorders and Mechanisms of Ectopic Calcification. In Genetics of Bone Biology and Skeletal Disease, 2nd ed.; Academic Press: San Diego, CA, USA, 2018; pp. 571-595. ISBN 978-0-12-804182-6.

50. Opdebeeck, B.; Orriss, I.R.; Neven, E.; D'Haese, P.C.; Verhulst, A. Extracellular Nucleotides Regulate Arterial Calcification by Activating Both Independent and Dependent Purinergic Receptor Signaling Pathways. Int. J. Mol. Sci. 2020, 21, 7636. [CrossRef]

51. Rilla, K.; Mustonen, A.-M.; Arasu, U.T.; Härkönen, K.; Matilainen, J.; Nieminen, P. Extracellular Vesicles Are Integral and Functional Components of the Extracellular Matrix. Matrix Biol. 2019, 75-76, 201-219. [CrossRef]

52. Azoidis, I.; Cox, S.C.; Davies, O.G. The Role of Extracellular Vesicles in Biomineralisation: Current Perspective and Application in Regenerative Medicine. J. Tissue Eng. 2018, 9. [CrossRef] [PubMed]

53. Kapustin, A.N.; Chatrou, M.L.L.; Drozdov, I.; Zheng, Y.; Davidson, S.M.; Soong, D.; Furmanik, M.; Sanchis, P.; De Rosales, R.T.M.; Alvarez-Hernandez, D.; et al. Vascular Smooth Muscle Cell Calcification Is Mediated by Regulated Exosome Secretion. Circ. Res. 2015, 116, 1312-1323. [CrossRef] [PubMed]

54. Majeska, R.J.; Wuthier, R.E. Studies on Matrix Vesicles Isolated from Chick Epiphyseal Cartilage. Association of Pyrophosphatase and ATPase Activities with Alkaline Phosphatase. Biochim. Biophys. Acta 1975, 391, 51-60. [CrossRef] 
55. Fedde, K.N. Human Osteosarcoma Cells Spontaneously Release Matrix-Vesicle-like Structures with the Capacity to Mineralize. Bone Miner. 1992, 17, 145-151. [CrossRef]

56. Anderson, H.C. Matrix Vesicles and Calcification. Curr. Rheumatol. Rep. 2003, 5, 222-226. [CrossRef] [PubMed]

57. Cui, L.; Houston, D.A.; Farquharson, C.; MacRae, V.E. Characterisation of Matrix Vesicles in Skeletal and Soft Tissue Mineralisation. Bone 2016, 87, 147-158. [CrossRef]

58. Hsu, H.H.; Camacho, N.P. Isolation of Calcifiable Vesicles from Human Atherosclerotic Aortas. Atherosclerosis 1999, 143, 353-362. [CrossRef]

59. Shao, J.-S.; Cai, J.; Towler, D.A. Molecular Mechanisms of Vascular Calcification: Lessons Learned from the Aorta. Arterioscler. Thromb. Vasc. Biol. 2006, 26, 1423-1430. [CrossRef]

60. Golub, E.E. Biomineralization and Matrix Vesicles in Biology and Pathology. Semin. Immunopathol. 2011, 33, 409-417. [CrossRef]

61. Golub, E. Role of Matrix Vesicles in Biomineralization. Biochim. Biophys. Acta 2009, 1790, 1592-1598. [CrossRef]

62. Gurley, K.A.; Reimer, R.J.; Kingsley, D.M. Biochemical and Genetic Analysis of ANK in Arthritis and Bone Disease. Am. J. Hum. Genet. 2006, 79, 1017-1029. [CrossRef] [PubMed]

63. Ho, A.M.; Johnson, M.D.; Kingsley, D.M. Role of the Mouse Ank Gene in Control of Tissue Calcification and Arthritis. Science 2000, 289, 265-270. [CrossRef] [PubMed]

64. Costello, J.C.; Rosenthal, A.K.; Kurup, I.V.; Masuda, I.; Medhora, M.; Ryan, L.M. Parallel Regulation of Extracellular ATP and Inorganic Pyrophosphate: Roles of Growth Factors, Transduction Modulators, and ANK. Connect. Tissue Res. 2011, 52, 139-146. [CrossRef] [PubMed]

65. Szeri, F.; Lundkvist, S.; Donnelly, S.; Engelke, U.F.H.; Rhee, K.; Williams, C.J.; Sundberg, J.P.; Wevers, R.A.; Tomlinson, R.E.; Jansen, R.S.; et al. The Membrane Protein ANKH Is Crucial for Bone Mechanical Performance by Mediating Cellular Export of Citrate and ATP. PLoS Genet. 2020, 16, e1008884. [CrossRef] [PubMed]

66. Boskey, A.L.; Maresca, M.; Ullrich, W.; Doty, S.B.; Butler, W.T.; Prince, C.W. Osteopontin-Hydroxyapatite Interactions in Vitro: Inhibition of Hydroxyapatite Formation and Growth in a Gelatin-Gel. Bone Miner. 1993, 22, 147-159. [CrossRef]

67. Roberts, S.; Narisawa, S.; Harmey, D.; Millán, J.L.; Farquharson, C. Functional Involvement of PHOSPHO1 in Matrix VesicleMediated Skeletal Mineralization. J. Bone Miner. Res. 2007, 22, 617-627. [CrossRef] [PubMed]

68. Hasegawa, T.; Yamamoto, T.; Tsuchiya, E.; Hongo, H.; Tsuboi, K.; Kudo, A.; Abe, M.; Yoshida, T.; Nagai, T.; Khadiza, N.; et al. Ultrastructural and Biochemical Aspects of Matrix Vesicle-Mediated Mineralization. Jpn. Dent. Sci. Rev. 2017, 53, 34-45. [CrossRef]

69. Orimo, H. The Mechanism of Mineralization and the Role of Alkaline Phosphatase in Health and Disease. J. Nippon Med. Sch. 2010, 77, 4-12. [CrossRef]

70. Kirsch, T. Annexins-Their Role in Cartilage Mineralization. Front. Biosci. 2005, 10, 576-581. [CrossRef]

71. Kockx, M.M.; Muhring, J.; Bortier, H.; De Meyer, G.R.; Jacob, W. Biotin- or Digoxigenin-Conjugated Nucleotides Bind to Matrix Vesicles in Atherosclerotic Plaques. Am. J. Pathol. 1996, 148, 1771-1777.

72. Hashimoto, S.; Ochs, R.L.; Rosen, F.; Quach, J.; McCabe, G.; Solan, J.; Seegmiller, J.E.; Terkeltaub, R.; Lotz, M. Chondrocyte-Derived Apoptotic Bodies and Calcification of Articular Cartilage. Proc. Natl. Acad. Sci. USA 1998, 95, 3094-3099. [CrossRef] [PubMed]

73. Proudfoot, D.; Skepper, J.N.; Hegyi, L.; Bennett, M.R.; Shanahan, C.M.; Weissberg, P.L. Apoptosis Regulates Human Vascular Calcification in Vitro: Evidence for Initiation of Vascular Calcification by Apoptotic Bodies. Circ. Res. 2000, 87, $1055-1062$. [CrossRef] [PubMed]

74. Kirsch, T.; Wang, W.; Pfander, D. Functional Differences Between Growth Plate Apoptotic Bodies and Matrix Vesicles. J. Bone Miner. Res. 2003, 18, 1872-1881. [CrossRef] [PubMed]

75. Wang, P.; Zhang, N.; Wu, B.; Wu, S.; Zhang, Y.; Sun, Y. The Role of Mitochondria in Vascular Calcification. J. Transl. Int. Med. 2020, 8, 80-90. [CrossRef] [PubMed]

76. Abate, M.; Festa, A.; Falco, M.; Lombardi, A.; Luce, A.; Grimaldi, A.; Zappavigna, S.; Sperlongano, P.; Irace, C.; Caraglia, M.; et al. Mitochondria as Playmakers of Apoptosis, Autophagy and Senescence. Semin. Cell Dev. Biol. 2020, 98, 139-153. [CrossRef]

77. Bonucci, E.; Derenzini, M.; Marinozzi, V. The Organic-Inorganic Relationship in Calcified Mitochondria. J. Cell Biol. 1973, 59, 185. [CrossRef]

78. Weinbach, E.C.; Von Brand, T. Formation, Isolation and Composition of Dense Granules from Mitochondria. Biochim. Biophys. Acta 1967, 148, 256-266. [CrossRef]

79. Halstead, L.B. Are Mitochondria Directly Involved in Biological Mineralisation? The Mitochondrion and the Origin of Bone. Calcified Tissue Res. 1969, 3, 103-105. [CrossRef]

80. Martin, J.H.; Matthews, J.L. Mitochondrial Granules in Chondrocytes, Osteoblasts and Osteocytes. An Ultrastructural and Microincineration Study. Clin. Orthop. Relat. Res. 1970, 68, 273-278. [CrossRef]

81. Holtrop, M.E. The Ultrastructure of the Epiphyseal Plate. I. The Flattened Chondrocyte. Calcif. Tissue Res. 1972, 9, 131-139. [CrossRef]

82. Brighton, C.T.; Hunt, R.M. Mitochondrial Calcium and Its Role in Calcification. Histochemical Localization of Calcium in Electron Micrographs of the Epiphyseal Growth Plate with K-Pyroantimonate. Clin. Orthop. Relat. Res. 1974, 100, 406-416. [CrossRef]

83. Anderson, H.C. Mechanisms of Pathologic Calcification. Rheum. Dis. Clin. N. Am. 1988, 14, 303-319.

84. Omelon, S.; Ariganello, M.; Bonucci, E.; Grynpas, M.; Nanci, A. A Review of Phosphate Mineral Nucleation in Biology and Geobiology. Calcif. Tissue Int. 2013, 93, 382-396. [CrossRef] [PubMed] 
85. Fenton, A.R.; Jongens, T.A.; Holzbaur, E.L.F. Mitochondrial Dynamics: Shaping and Remodeling an Organelle Network. Curr. Opin. Cell Biol. 2020, 68, 28-36. [CrossRef]

86. Wolf, C.; López Del Amo, V.; Arndt, S.; Bueno, D.; Tenzer, S.; Hanschmann, E.M.; Berndt, C.; Methner, A. Redox Modifications of Proteins of the Mitochondrial Fusion and Fission Machinery. Cells 2020, 9, 815. [CrossRef]

87. Chen, W.R.; Zhou, Y.J.; Sha, Y.; Wu, X.P.; Yang, J.Q.; Liu, F. Melatonin Attenuates Vascular Calcification by Inhibiting Mitochondria Fission via an AMPK/Drp1 Signalling Pathway. J. Cell Mol. Med. 2020, 24, 6043-6054. [CrossRef]

88. Forrester Steven, J.; Kikuchi Daniel, S.; Hernandes Marina, S.; Xu, Q.; Griendling Kathy, K. Reactive Oxygen Species in Metabolic and Inflammatory Signaling. Circ. Res. 2018, 122, 877-902. [CrossRef]

89. Liaudet, L.; Vassalli, G.; Pacher, P. Role of Peroxynitrite in the Redox Regulation of Cell Signal Transduction Pathways. Front. Biosci. 2009, 14, 4809-4814. [CrossRef]

90. Moldogazieva, N.T.; Mokhosoev, I.M.; Feldman, N.B.; Lutsenko, S.V. ROS and RNS Signalling: Adaptive Redox Switches through Oxidative/Nitrosative Protein Modifications. Free Radic. Res. 2018, 52, 507-543. [CrossRef]

91. Ljubuncic, P.; Bar-Shai, M.; Reznick, A. The Role of Reactive Nitrogen Species (RNS) in the Activation of Nuclear Factor Kappa B (NFkB) and Its Implications for Biological Systems: The Question of Balance. In Oxidants in Biology: A Question of Balance; Springer: Dordrecht, The Netherlands, 2008; pp. 67-109, ISBN 978-1-4020-8398-3.

92. Lingappan, K. NF-KB in Oxidative Stress. Curr. Opin. Toxicol. 2018, 7, 81. [CrossRef]

93. Zhao, G.; Xu, M.; Zhao, M.; Dai, X.; Kong, W.; Wilson, G.; Guan, Y.; Wang, C.; Wang, X. Activation of Nuclear FactorKappa B Accelerates Vascular Calcification by Inhibiting Ankylosis Protein Homolog Expression. Kidney Int. 2012, 82, 34-44. [CrossRef] [PubMed]

94. Yamada, S.; Taniguchi, M.; Tokumoto, M.; Toyonaga, J.; Fujisaki, K.; Suehiro, T.; Noguchi, H.; Iida, M.; Tsuruya, K.; Kitazono, T. The Antioxidant Tempol Ameliorates Arterial Medial Calcification in Uremic Rats: Important Role of Oxidative Stress in the Pathogenesis of Vascular Calcification in Chronic Kidney Disease. J. Bone Miner. Res. 2012, 27, 474-485. [CrossRef] [PubMed]

95. Yoshida, T.; Yamashita, M.; Horimai, C.; Hayashi, M. Smooth Muscle-Selective Nuclear Factor-KB Inhibition Reduces Phosphate-Induced Arterial Medial Calcification in Mice with Chronic Kidney Disease. J. Am. Heart Assoc. 2017, 6, e007248. [CrossRef] [PubMed]

96. Funato, Y.; Miki, H. Redox Regulation of Wnt Signalling via Nucleoredoxin. Free Radic. Res. 2010, 44, 379-388. [CrossRef]

97. Bandara, N.; Gurusinghe, S.; Lim, S.Y.; Chen, H.; Chen, S.; Wang, D.; Hilbert, B.; Wang, L.-X.; Strappe, P. Molecular Control of Nitric Oxide Synthesis through ENOS and Caveolin-1 Interaction Regulates Osteogenic Differentiation of Adipose-Derived Stem Cells by Modulation of Wnt/ $\beta$-Catenin Signaling. Stem. Cell Res. Ther. 2016, 7, 182. [CrossRef]

98. Ma, B.; Hottiger, M.O. Crosstalk between Wnt/ $\beta$-Catenin and NF-KB Signaling Pathway during Inflammation. Front. Immunol. 2016, 7. [CrossRef]

99. Al-Aly, Z.; Shao, J.-S.; Lai, C.-F.; Huang, E.; Cai, J.; Behrmann, A.; Cheng, S.-L.; Towler, D.A. Aortic Msx2-Wnt Calcification Cascade Is Regulated by TNF-Alpha-Dependent Signals in Diabetic Ldlr-/- Mice. Arterioscler. Thromb. Vasc. Biol. 2007, 27, 2589-2596. [CrossRef]

100. Byon, C.H.; Javed, A.; Dai, Q.; Kappes, J.C.; Clemens, T.L.; Darley-Usmar, V.M.; McDonald, J.M.; Chen, Y. Oxidative Stress Induces Vascular Calcification through Modulation of the Osteogenic Transcription Factor Runx2 by AKT Signaling. J. Biol. Chem. 2008, 283, 15319-15327. [CrossRef]

101. Byon, C.H.; Heath, J.M.; Chen, Y. Redox Signaling in Cardiovascular Pathophysiology: A Focus on Hydrogen Peroxide and Vascular Smooth Muscle Cells. Redox Biol. 2016, 9, 244-253. [CrossRef]

102. Hruska, K.A.; Mathew, S.; Saab, G. Bone Morphogenetic Proteins in Vascular Calcification. Circ. Res. 2005, 97, 105-114. [CrossRef]

103. Johnson, K.A.; Polewski, M.; Terkeltaub, R.A. Transglutaminase 2 Is Central to Induction of the Arterial Calcification Program by Smooth Muscle Cells. Circ. Res. 2008, 102, 529-537. [CrossRef] [PubMed]

104. Mandal, C.C.; Ganapathy, S.; Gorin, Y.; Mahadev, K.; Block, K.; Abboud, H.E.; Harris, S.E.; Ghosh-Choudhury, G.; GhoshChoudhury, N. Reactive Oxygen Species Derived from Nox4 Mediate BMP2 Gene Transcription and Osteoblast Differentiation. Biochem. J. 2011, 433, 393-402. [CrossRef] [PubMed]

105. Cheng, S.L.; Shao, J.S.; Charlton-Kachigian, N.; Loewy, A.P.; Towler, D.A. MSX2 Promotes Osteogenesis and Suppresses Adipogenic Differentiation of Multipotent Mesenchymal Progenitors. J. Biol. Chem. 2003, 278, 45969-45977. [CrossRef] [PubMed]

106. Ducy, P.; Zhang, R.; Geoffroy, V.; Ridall, A.L.; Karsenty, G. Osf2/Cbfa1: A Transcriptional Activator of Osteoblast Differentiation. Cell 1997, 89, 747-754. [CrossRef]

107. Komori, T. Regulation of Bone Development and Extracellular Matrix Protein Genes by RUNX2. Cell Tissue Res. 2010, 339, 189-195. [CrossRef]

108. Roughley, P.J. Articular Cartilage and Changes in Arthritis: Noncollagenous Proteins and Proteoglycans in the Extracellular Matrix of Cartilage. Arthritis Res. 2001, 3, 342-347. [CrossRef]

109. Hunziker, E.B. Mechanism of Longitudinal Bone Growth and Its Regulation by Growth Plate Chondrocytes. Microsc. Res. Tech. 1994, 28, 505-519. [CrossRef]

110. Szuwart, T.; Kierdorf, H.; Kierdorf, U.; Clemen, G. Ultrastructural Aspects of Cartilage Formation, Mineralization, and Degeneration during Primary Antler Growth in Fallow Deer (Dama Dama). Ann. Anat. 1998, 180, 501-510. [CrossRef]

111. Messner, K. Postnatal Development of the Cruciate Ligament Insertions in the Rat Knee. Morphological Evaluation and Immunohistochemical Study of Collagens Types I and II. Cells Tissues Organs 1997, 160, 261-268. [CrossRef] 
112. Sun, M.M.G.; Beier, F. Chondrocyte Hypertrophy in Skeletal Development, Growth, and Disease. Birth Defects Res. C Embryo Today Rev. 2014, 102, 74-82. [CrossRef]

113. Lefebvre, V.; Smits, P. Transcriptional Control of Chondrocyte Fate and Differentiation. Birth Defects Res. C Embryo Today Rev. 2005, 75, 200-212. [CrossRef] [PubMed]

114. Adams, C.S.; Shapiro, I.M. The Fate of the Terminally Differentiated Chondrocyte: Evidence for Microenvironmental Regulation of Chondrocyte Apoptosis. Crit. Rev. Oral Biol. Med. 2002, 13, 465-473. [CrossRef] [PubMed]

115. Shapiro, I.M.; Adams, C.S.; Freeman, T.; Srinivas, V. Fate of the Hypertrophic Chondrocyte: Microenvironmental Perspectives on Apoptosis and Survival in the Epiphyseal Growth Plate. Birth Defects Res. C Embryo Today Rev. 2005, 75, 330-339. [CrossRef] [PubMed]

116. Wang, L.; Huang, J.; Moore, D.C.; Zuo, C.; Wu, Q.; Xie, L.; von der Mark, K.; Yuan, X.; Chen, D.; Warman, M.L.; et al. SHP2 Regulates the Osteogenic Fate of Growth Plate Hypertrophic Chondrocytes. Sci. Rep. 2017, 7, 12699. [CrossRef]

117. van der Kraan, P.M.; van den Berg, W.B. Chondrocyte Hypertrophy and Osteoarthritis: Role in Initiation and Progression of Cartilage Degeneration? Osteoarthr. Cartil. 2012, 20, 223-232. [CrossRef] [PubMed]

118. Liu-Bryan, R.; Terkeltaub, R. Emerging Regulators of the Inflammatory Process in Osteoarthritis. Nat. Rev. Rheumatol. 2015, 11, 35-44. [CrossRef] [PubMed]

119. Choi, M.C.; Jo, J.; Park, J.; Kang, H.K.; Park, Y. NF-KB Signaling Pathways in Osteoarthritic Cartilage Destruction. Cells 2019, 8, 734. [CrossRef] [PubMed]

120. Blanco, F.J.; Guitian, R.; Vázquez-Martul, E.; de Toro, F.J.; Galdo, F. Osteoarthritis Chondrocytes Die by Apoptosis. A Possible Pathway for Osteoarthritis Pathology. Arthritis Rheum. 1998, 41, 284-289. [CrossRef]

121. Sharif, M.; Whitehouse, A.; Sharman, P.; Perry, M.; Adams, M. Increased Apoptosis in Human Osteoarthritic Cartilage Corresponds to Reduced Cell Density and Expression of Caspase-3. Arthritis Rheum. 2004, 50, 507-515. [CrossRef]

122. Huppertz, B.; Frank, H.G.; Kaufmann, P. The Apoptosis Cascade-Morphological and Immunohistochemical Methods for Its Visualization. Anat. Embryol. 1999, 200,1-18. [CrossRef]

123. Musumeci, G.; Loreto, C.; Carnazza, M.L.; Martinez, G. Characterization of Apoptosis in Articular Cartilage Derived from the Knee Joints of Patients with Osteoarthritis. Knee Surg. Sports Traumatol. Arthrosc. 2011, 19, 307-313. [CrossRef] [PubMed]

124. Zamli, Z.; Sharif, M. Chondrocyte Apoptosis: A Cause or Consequence of Osteoarthritis? Int. J. Rheum. Dis. 2011, 14, 159-166. [CrossRef] [PubMed]

125. Chen, C.T.; Burton-Wurster, N.; Borden, C.; Hueffer, K.; Bloom, S.E.; Lust, G. Chondrocyte Necrosis and Apoptosis in Impact Damaged Articular Cartilage. J. Orthop. Res. 2001, 19, 703-711. [CrossRef]

126. Kourí, J.B.; Aguilera, J.M.; Reyes, J.; Lozoya, K.A.; González, S. Apoptotic Chondrocytes from Osteoarthrotic Human Articular Cartilage and Abnormal Calcification of Subchondral Bone. J. Rheumatol. 2000, 27, 1005-1019.

127. Thomas, C.M.; Fuller, C.J.; Whittles, C.E.; Sharif, M. Chondrocyte Death by Apoptosis Is Associated with Cartilage Matrix Degradation. Osteoarthr. Cartil. 2007, 15, 27-34. [CrossRef]

128. Roach, H.I.; Aigner, T.; Kouri, J.B. Chondroptosis: A Variant of Apoptotic Cell Death in Chondrocytes? Apoptosis 2004, 9 , 265-277. [CrossRef]

129. Almonte-Becerril, M.; Navarro-Garcia, F.; Gonzalez-Robles, A.; Vega-Lopez, M.A.; Lavalle, C.; Kouri, J.B. Cell Death of Chondrocytes Is a Combination between Apoptosis and Autophagy during the Pathogenesis of Osteoarthritis within an Experimental Model. Apoptosis 2010, 15, 631-638. [CrossRef]

130. Johnson, K.; Pritzker, K.; Goding, J.; Terkeltaub, R. The Nucleoside Triphosphate Pyrophosphohydrolase Isozyme PC-1 Directly Promotes Cartilage Calcification through Chondrocyte Apoptosis and Increased Calcium Precipitation by Mineralizing Vesicles. J. Rheumatol. 2001, 28, 2681-2691.

131. Hashimoto, S.; Ochs, R.L.; Komiya, S.; Lotz, M. Linkage of Chondrocyte Apoptosis and Cartilage Degradation in Human Osteoarthritis. Arthritis Rheum. 1998, 41, 1632-1638. [CrossRef]

132. Jiao, K.; Zhang, J.; Zhang, M.; Wei, Y.; Wu, Y.; Qiu, Z.Y.; He, J.; Cao, Y.; Hu, J.; Zhu, H.; et al. The Identification of CD163 Expressing Phagocytic Chondrocytes in Joint Cartilage and Its Novel Scavenger Role in Cartilage Degradation. PLoS ONE 2013, 8, e53312. [CrossRef]

133. Kirsch, T.; Swoboda, B.; Nah, H. Activation of Annexin II and V Expression, Terminal Differentiation, Mineralization and Apoptosis in Human Osteoarthritic Cartilage. Osteoarthr. Cartil. 2000, 8, 294-302. [CrossRef] [PubMed]

134. Mitsuyama, H.; Healey, R.M.; Terkeltaub, R.A.; Coutts, R.D.; Amiel, D. Calcification of Human Articular Knee Cartilage Is Primarily an Effect of Aging Rather than Osteoarthritis. Osteoarthr. Cartil. 2007, 15, 559-565. [CrossRef] [PubMed]

135. Blanco, F.J.; Ochs, R.L.; Schwarz, H.; Lotz, M. Chondrocyte Apoptosis Induced by Nitric Oxide. Am. J. Pathol. 1995, 146, 75-85. [PubMed]

136. Hashimoto, S.; Setareh, M.; Ochs, R.L.; Lotz, M. Fas/Fas Ligand Expression and Induction of Apoptosis in Chondrocytes. Arthritis Rheum. 1997, 40, 1749-1755. [CrossRef] [PubMed]

137. Boraldi, F.; Bartolomeo, A.; Di Bari, C.; Cocconi, A.; Quaglino, D. Donor's Age and Replicative Senescence Favour the in-Vitro Mineralization Potential of Human Fibroblasts. Exp. Gerontol. 2015, 72, 218-226. [CrossRef] [PubMed]

138. Boraldi, F.; Burns, J.S.; Bartolomeo, A.; Dominici, M.; Quaglino, D. Mineralization by Mesenchymal Stromal Cells Is Variously Modulated Depending on Commercial Platelet Lysate Preparations. Cytotherapy 2018, 20, 335-342. [CrossRef] 
139. Boraldi, F.; Moscarelli, P.; Lofaro, F.D.; Sabia, C.; Quaglino, D. The Mineralization Process of Insoluble Elastin Fibrillar Structures: Ionic Environment vs Degradation. Int. J. Biol. Macromol. 2020, 149, 693-706. [CrossRef]

140. Fujita, T.; Meguro, T.; Izumo, N.; Yasutomi, C.; Fukuyama, R.; Nakamuta, H.; Koida, M. Phosphate Stimulates Differentiation and Mineralization of the Chondroprogenitor Clone ATDC5. Jnp. J. Pharmacol. 2001, 85, 278-281. [CrossRef]

141. Magne, D.; Bluteau, G.; Faucheux, C.; Palmer, G.; Vignes-Colombeix, C.; Pilet, P.; Rouillon, T.; Caverzasio, J.; Weiss, P.; Daculsi, G.; et al. Phosphate Is a Specific Signal for ATDC5 Chondrocyte Maturation and Apoptosis-Associated Mineralization: Possible Implication of Apoptosis in the Regulation of Endochondral Ossification. J. Bone Miner. Res. 2003, 18, 1430-1442. [CrossRef]

142. Yuan, F.L.; Xu, R.S.; Ye, J.X.; Zhao, M.D.; Ren, L.J.; Li, X. Apoptotic Bodies from Endplate Chondrocytes Enhance the Oxidative Stress-Induced Mineralization by Regulating PPi Metabolism. J. Cell Mol. Med. 2019, 23, 3665-3675. [CrossRef]

143. Ea, H.K.; Uzan, B.; Rey, C.; Lioté, F. Octacalcium Phosphate Crystals Directly Stimulate Expression of Inducible Nitric Oxide Synthase through P38 and JNK Mitogen-Activated Protein Kinases in Articular Chondrocytes. Arthritis Res. Ther. 2005, 7, R915-R926. [CrossRef] [PubMed]

144. Ea, H.K.; Monceau, V.; Camors, E.; Cohen-Solal, M.; Charlemagne, D.; Lioté, F. Annexin 5 Overexpression Increased Articular Chondrocyte Apoptosis Induced by Basic Calcium Phosphate Crystals. Ann. Rheum. Dis. 2008, 67, 1617-1625. [CrossRef] [PubMed]

145. Nguyen, C.; Lieberherr, M.; Bordat, C.; Velard, F.; Côme, D.; Lioté, F.; Ea, H.-K. Intracellular Calcium Oscillations in Articular Chondrocytes Induced by Basic Calcium Phosphate Crystals Lead to Cartilage Degradation. Osteoarthr. Cartil. 2012, 20, 1399-1408. [CrossRef] [PubMed]

146. Wang, W.; Xu, J.; Kirsch, T. Annexin-Mediated Ca2+ Influx Regulates Growth Plate Chondrocyte Maturation and Apoptosis. J. Biol. Chem. 2003, 278, 3762-3769. [CrossRef]

147. Ea, H.-K.; Chobaz, V.; Nguyen, C.; Nasi, S.; van Lent, P.; Daudon, M.; Dessombz, A.; Bazin, D.; McCarthy, G.; Jolles-Haeberli, B.; et al. Pathogenic Role of Basic Calcium Phosphate Crystals in Destructive Arthropathies. PLoS ONE 2013, 8, e57352. [CrossRef]

148. McCarthy, G.M.; Dunne, A. Calcium Crystal Deposition Diseases-Beyond Gout. Nat. Rev. Rheumatol. 2018, 14, 592-602. [CrossRef]

149. Blasioli, D.J.; Kaplan, D.L. The Roles of Catabolic Factors in the Development of Osteoarthritis. Tissue Eng. Part B Rev. 2014, 20, 355-363. [CrossRef]

150. Ripmeester, E.G.J.; Timur, U.T.; Caron, M.M.J.; Welting, T.J.M. Recent Insights into the Contribution of the Changing Hypertrophic Chondrocyte Phenotype in the Development and Progression of Osteoarthritis. Front. Bioeng. Biotechnol. 2018, 6, 18. [CrossRef]

151. Heinegård, D.; Saxne, T. The Role of the Cartilage Matrix in Osteoarthritis. Nat. Rev. Rheumatol. 2011, 7, 50-56. [CrossRef]

152. Homandberg, G.A.; Hui, F.; Wen, C.; Kuettner, K.E.; Williams, J.M. Hyaluronic Acid Suppresses Fibronectin Fragment Mediated Cartilage Chondrolysis: I. In Vitro. Osteoarthr. Cartil. 1997, 5, 309-319. [CrossRef]

153. Lark, M.W.; Bayne, E.K.; Flanagan, J.; Harper, C.F.; Hoerrner, L.A.; Hutchinson, N.I.; Singer, I.I.; Donatelli, S.A.; Weidner, J.R.; Williams, H.R.; et al. Aggrecan Degradation in Human Cartilage. Evidence for Both Matrix Metalloproteinase and Aggrecanase Activity in Normal, Osteoarthritic, and Rheumatoid Joints. J. Clin. Investig. 1997, 100, 93-106. [CrossRef] [PubMed]

154. Tchetina, E.V.; Kobayashi, M.; Yasuda, T.; Meijers, T.; Pidoux, I.; Poole, A.R. Chondrocyte Hypertrophy Can Be Induced by a Cryptic Sequence of Type II Collagen and Is Accompanied by the Induction of MMP-13 and Collagenase Activity: Implications for Development and Arthritis. Matrix Biol. 2007, 26, 247-258. [CrossRef] [PubMed]

155. DeGroot, J. The AGE of the Matrix: Chemistry, Consequence and Cure. Curr. Opin. Pharmacol. 2004, 4, 301-305. [CrossRef] [PubMed]

156. DeGroot, J.; Verzijl, N.; Bank, R.A.; Lafeber, F.P.; Bijlsma, J.W.; TeKoppele, J.M. Age-Related Decrease in Proteoglycan Synthesis of Human Articular Chondrocytes: The Role of Nonenzymatic Glycation. Arthritis Rheum. 1999, 42, 1003-1009. [CrossRef]

157. Loeser, R.F.; Yammani, R.R.; Carlson, C.S.; Chen, H.; Cole, A.; Im, H.-J.; Bursch, L.S.; Yan, S.D. Articular Chondrocytes Express the Receptor for Advanced Glycation End Products: Potential Role in Osteoarthritis. Arthritis Rheum. 2005, 52, 2376-2385. [CrossRef]

158. Kim, H.A.; Suh, D.I.; Song, Y.W. Relationship between Chondrocyte Apoptosis and Matrix Depletion in Human Articular Cartilage. J. Rheumatol. 2001, 28, 2038-2045.

159. Loeser, R.F. Integrins and Chondrocyte-Matrix Interactions in Articular Cartilage. Matrix Biol. 2014, 39, 11-16. [CrossRef]

160. Pulai, J.I.; Del Carlo, M.; Loeser, R.F. The Alpha5beta1 Integrin Provides Matrix Survival Signals for Normal and Osteoarthritic Human Articular Chondrocytes in Vitro. Arthritis Rheum. 2002, 46, 1528-1535. [CrossRef]

161. Almonte-Becerril, M.; Costell, M.; Kouri, J.B. Changes in the Integrins Expression Are Related with the Osteoarthritis Severity in an Experimental Animal Model in Rats. J. Orthop. Res. 2014, 32, 1161-1166. [CrossRef]

162. Zemmyo, M.; Meharra, E.J.; Kühn, K.; Creighton-Achermann, L.; Lotz, M. Accelerated, Aging-Dependent Development of Osteoarthritis in A1 Integrin-Deficient Mice. Arthritis Rheum. 2003, 48, 2873-2880. [CrossRef]

163. Pennock, A.T.; Robertson, C.M.; Emmerson, B.C.; Harwood, F.L.; Amiel, D. Role of Apoptotic and Matrix-Degrading Genes in Articular Cartilage and Meniscus of Mature and Aged Rabbits during Development of Osteoarthritis. Arthritis Rheum. 2007, 56, 1529-1536. [CrossRef] [PubMed]

164. Wei, L.; Sun, X.; Wang, Z.; Chen, Q. CD95-Induced Osteoarthritic Chondrocyte Apoptosis and Necrosis: Dependency on P38 Mitogen-Activated Protein Kinase. Arthritis Res. Ther. 2006, 8, R37. [CrossRef] [PubMed]

165. Kim, H.A.; Lee, Y.J.; Seong, S.C.; Choe, K.W.; Song, Y.W. Apoptotic Chondrocyte Death in Human Osteoarthritis. J. Rheumatol. 2000, 27, 455-462. [PubMed]

166. Ryu, J.-H.; Shin, Y.; Huh, Y.H.; Yang, S.; Chun, C.-H.; Chun, J.-S. Hypoxia-Inducible Factor-2 $\alpha$ Regulates Fas-Mediated Chondrocyte Apoptosis during Osteoarthritic Cartilage Destruction. Cell Death Differ. 2012, 19, 440-450. [CrossRef] 
167. Yang, S.; Kim, J.; Ryu, J.-H.; Oh, H.; Chun, C.-H.; Kim, B.J.; Min, B.H.; Chun, J.-S. Hypoxia-Inducible Factor-2 $\alpha$ Is a Catabolic Regulator of Osteoarthritic Cartilage Destruction. Nat. Med. 2010, 16, 687-693. [CrossRef]

168. Goldring, S.R.; Goldring, M.B. The Role of Cytokines in Cartilage Matrix Degeneration in Osteoarthritis. Clin. Orthop. Relat. Res. 2004, S27-S36. [CrossRef]

169. Mengshol, J.A.; Vincenti, M.P.; Coon, C.I.; Barchowsky, A.; Brinckerhoff, C.E. Interleukin-1 Induction of Collagenase 3 (Matrix Metalloproteinase 13) Gene Expression in Chondrocytes Requires P38, c-Jun N-Terminal Kinase, and Nuclear Factor KappaB: Differential Regulation of Collagenase 1 and Collagenase 3. Arthritis Rheum. 2000, 43, 801-811. [CrossRef]

170. Verma, P.; Dalal, K. ADAMTS-4 and ADAMTS-5: Key Enzymes in Osteoarthritis. J. Cell. Biochem. 2011, 112, 3507-3514. [CrossRef]

171. Séguin, C.A.; Bernier, S.M. TNFalpha Suppresses Link Protein and Type II Collagen Expression in Chondrocytes: Role of MEK1/2 and NF-KappaB Signaling Pathways. J. Cell. Physiol. 2003, 197, 356-369. [CrossRef]

172. Martel-Pelletier, J.; Pelletier, J.-P.; Fahmi, H. Cyclooxygenase-2 and Prostaglandins in Articular Tissues. Semin. Arthritis Rheum. 2003, 33, 155-167. [CrossRef]

173. Attur, M.G.; Patel, I.R.; Patel, R.N.; Abramson, S.B.; Amin, A.R. Autocrine Production of IL-1 Beta by Human OsteoarthritisAffected Cartilage and Differential Regulation of Endogenous Nitric Oxide, IL-6, Prostaglandin E2, and IL-8. Proc. Assoc. Am. Physicians 1998, 110, 65-72. [PubMed]

174. Davies, C.M.; Guilak, F.; Weinberg, J.B.; Fermor, B. Reactive Nitrogen and Oxygen Species in Interleukin-1-Mediated DNA Damage Associated with Osteoarthritis. Osteoarthr. Cartil. 2008, 16, 624-630. [CrossRef] [PubMed]

175. Kim, J.; Xu, M.; Xo, R.; Mates, A.; Wilson, G.L.; Pearsall, A.W.; Grishko, V. Mitochondrial DNA Damage Is Involved in Apoptosis Caused by Pro-Inflammatory Cytokines in Human OA Chondrocytes. Osteoarthr. Cartil. 2010, 18, 424-432. [CrossRef] [PubMed]

176. Hattori, Y.; Kojima, T.; Kato, D.; Matsubara, H.; Takigawa, M.; Ishiguro, N. A Selective Estrogen Receptor Modulator Inhibits Tumor Necrosis Factor- $\alpha$-Induced Apoptosis through the ERK1/2 Signaling Pathway in Human Chondrocytes. Biochem. Biophys. Res Commun 2012, 421, 418-424. [CrossRef] [PubMed]

177. Sabio, G.; Davis, R.J. TNF and MAP Kinase Signaling Pathways. Semin. Immunol. 2014, 26, 237-245. [CrossRef] [PubMed]

178. Maneiro, E.; Martín, M.A.; de Andres, M.C.; López-Armada, M.J.; Fernández-Sueiro, J.L.; del Hoyo, P.; Galdo, F.; Arenas, J.; Blanco, F.J. Mitochondrial Respiratory Activity Is Altered in Osteoarthritic Human Articular Chondrocytes. Arthritis Rheum. 2003, 48, 700-708. [CrossRef]

179. Petit, P.X.; Zamzami, N.; Vayssière, J.L.; Mignotte, B.; Kroemer, G.; Castedo, M. Implication of Mitochondria in Apoptosis. Mol. Cell. Biochem. 1997, 174, 185-188. [CrossRef]

180. Huser, C.A.M.; Davies, M.E. Calcium Signaling Leads to Mitochondrial Depolarization in Impact-Induced Chondrocyte Death in Equine Articular Cartilage Explants. Arthritis Rheum. 2007, 56, 2322-2334. [CrossRef]

181. Ruiz-Romero, C.; Calamia, V.; Mateos, J.; Carreira, V.; Martínez-Gomariz, M.; Fernández, M.; Blanco, F.J. Mitochondrial Dysregulation of Osteoarthritic Human Articular Chondrocytes Analyzed by Proteomics: A Decrease in Mitochondrial Superoxide Dismutase Points to a Redox Imbalance. Mol. Cell Proteom. 2009, 8, 172-189. [CrossRef]

182. Liu, H.; Li, Z.; Cao, Y.; Cui, Y.; Yang, X.; Meng, Z.; Wang, R. Effect of Chondrocyte Mitochondrial Dysfunction on Cartilage Degeneration: A Possible Pathway for Osteoarthritis Pathology at the Subcellular Level. Mol. Med. Rep. 2019, 20, 3308-3316. [CrossRef]

183. Brookes, P.S.; Yoon, Y.; Robotham, J.L.; Anders, M.W.; Sheu, S.-S. Calcium, ATP, and ROS: A Mitochondrial Love-Hate Triangle. Am. J. Physiol. Cell Physiol. 2004, 287, C817-C833. [CrossRef] [PubMed]

184. Andersson, D.A.; Gentry, C.; Moss, S.; Bevan, S. Transient Receptor Potential A1 Is a Sensory Receptor for Multiple Products of Oxidative Stress. J. Neurosci. 2008, 28, 2485-2494. [CrossRef] [PubMed]

185. Moilanen, L.J.; Hämäläinen, M.; Nummenmaa, E.; Ilmarinen, P.; Vuolteenaho, K.; Nieminen, R.M.; Lehtimäki, L.; Moilanen, E. Monosodium Iodoacetate-Induced Inflammation and Joint Pain Are Reduced in TRPA1 Deficient Mice-Potential Role of TRPA1 in Osteoarthritis. Osteoarthr. Cartil. 2015, 23, 2017-2026. [CrossRef]

186. Nummenmaa, E.; Hämäläinen, M.; Moilanen, L.J.; Paukkeri, E.-L.; Nieminen, R.M.; Moilanen, T.; Vuolteenaho, K.; Moilanen, E. Transient Receptor Potential Ankyrin 1 (TRPA1) Is Functionally Expressed in Primary Human Osteoarthritic Chondrocytes. Arthritis Res. Ther. 2016, 18, 185. [CrossRef] [PubMed]

187. Yin, S.; Zhang, L.; Ding, L.; Huang, Z.; Xu, B.; Li, X.; Wang, P.; Mao, J. Transient Receptor Potential Ankyrin 1 (Trpa1) Mediates Il-1 $\beta$-Induced Apoptosis in Rat Chondrocytes via Calcium Overload and Mitochondrial Dysfunction. J. Inflamm. 2018, 15, 27. [CrossRef] [PubMed]

188. Aigner, T.; Hemmel, M.; Neureiter, D.; Gebhard, P.M.; Zeiler, G.; Kirchner, T.; McKenna, L. Apoptotic Cell Death Is Not a Widespread Phenomenon in Normal Aging and Osteoarthritis Human Articular Knee Cartilage: A Study of Proliferation, Programmed Cell Death (Apoptosis), and Viability of Chondrocytes in Normal and Osteoarthritic Human Knee Cartilage. Arthritis Rheum. 2001, 44, 1304-1312. [CrossRef]

189. Han, Y.; Li, X.; Yan, M.; Yang, M.; Wang, S.; Pan, J.; Li, L.; Tan, J. Oxidative Damage Induces Apoptosis and Promotes Calcification in Disc Cartilage Endplate Cell through ROS/MAPK/NF-KB Pathway: Implications for Disc Degeneration. Biochem. Biophys. Res. Commun. 2019, 516, 1026-1032. [CrossRef]

190. Vaillancourt, F.; Fahmi, H.; Shi, Q.; Lavigne, P.; Ranger, P.; Fernandes, J.C.; Benderdour, M. 4-Hydroxynonenal Induces Apoptosis in Human Osteoarthritic Chondrocytes: The Protective Role of Glutathione-S-Transferase. Arthritis Res. Ther. 2008, 10, R107. [CrossRef] 
191. Li, D.; Ni, S.; Miao, K.-S.; Zhuang, C. PI3K/Akt and Caspase Pathways Mediate Oxidative Stress-Induced Chondrocyte Apoptosis. Cell Stress Chaperones 2019, 24, 195-202. [CrossRef]

192. Asada, S.; Fukuda, K.; Nishisaka, F.; Matsukawa, M.; Hamanisi, C. Hydrogen Peroxide Induces Apoptosis of Chondrocytes; Involvement of Calcium Ion and Extracellular Signal-Regulated Protein Kinase. Inflamm. Res. 2001, 50, 19-23. [CrossRef]

193. Pelletier, J.P.; Martel-Pelletier, J.; Abramson, S.B. Osteoarthritis, an Inflammatory Disease: Potential Implication for the Selection of New Therapeutic Targets. Arthritis Rheum. 2001, 44, 1237-1247. [CrossRef]

194. Scher, J.U.; Pillinger, M.H.; Abramson, S.B. Nitric Oxide Synthases and Osteoarthritis. Curr. Rheumatol. Rep. 2007, 9, 9-15. [CrossRef] [PubMed]

195. Yasuda, T. Cartilage Destruction by Matrix Degradation Products. Mod. Rheumatol. 2006, 16, 197-205. [CrossRef] [PubMed]

196. Kühn, K.; Lotz, M. Mechanisms of Sodium Nitroprusside-Induced Death in Human Chondrocytes. Rheumatol. Int. 2003, 23, 241-247. [CrossRef] [PubMed]

197. Del Carlo, M.; Loeser, R.F. Nitric Oxide-Mediated Chondrocyte Cell Death Requires the Generation of Additional Reactive Oxygen Species. Arthritis Rheum. 2002, 46, 394-403. [CrossRef] [PubMed]

198. Kühn, K.; D'Lima, D.D.; Hashimoto, S.; Lotz, M. Cell Death in Cartilage. Osteoarthr. Cartil. 2004, 12, 1-16. [CrossRef]

199. Whiteman, M.; Armstrong, J.S.; Cheung, N.S.; Siau, J.-L.; Rose, P.; Schantz, J.-T.; Jones, D.P.; Halliwell, B. Peroxynitrite Mediates Calcium-Dependent Mitochondrial Dysfunction and Cell Death via Activation of Calpains. FASEB J. 2004, 18, 1395-1397. [CrossRef]

200. Mirzamohammadi, F.; Papaioannou, G.; Kobayashi, T. MicroRNAs in Cartilage Development, Homeostasis, and Disease. Curr. Osteoporos. Rep. 2014, 12, 410-419. [CrossRef]

201. Makki, M.S.; Haseeb, A.; Haqqi, T.M. MicroRNA-9 Promotion of Interleukin-6 Expression by Inhibiting Monocyte Chemoattractant Protein-Induced Protein 1 Expression in Interleukin-1ß-Stimulated Human Chondrocytes. Arthritis Rheumatol. 2015, 67, 2117-2128. [CrossRef]

202. Li, F.; Yao, J.; Hao, Q.; Duan, Z. MiRNA-103 Promotes Chondrocyte Apoptosis by down-Regulation of Sphingosine Kinase-1 and Ameliorates PI3K/AKT Pathway in Osteoarthritis. Biosci. Rep. 2019, 39. [CrossRef]

203. Yan, S.; Wang, M.; Zhao, J.; Zhang, H.; Zhou, C.; Jin, L.; Zhang, Y.; Qiu, X.; Ma, B.; Fan, Q. MicroRNA-34a Affects Chondrocyte Apoptosis and Proliferation by Targeting the SIRT1/P53 Signaling Pathway during the Pathogenesis of Osteoarthritis. Int. J. Mol. Med. 2016, 38, 201-209. [CrossRef] [PubMed]

204. Abouheif, M.M.; Nakasa, T.; Shibuya, H.; Niimoto, T.; Kongcharoensombat, W.; Ochi, M. Silencing MicroRNA-34a Inhibits Chondrocyte Apoptosis in a Rat Osteoarthritis Model in Vitro. Rheumatology 2010, 49, 2054-2060. [CrossRef] [PubMed]

205. Zhang, M.; Wang, Z.; Li, B.; Sun, F.; Chen, A.; Gong, M. Identification of MicroRNA-363-3p as an Essential Regulator of Chondrocyte Apoptosis in Osteoarthritis by Targeting NRF1 through the P53-signaling Pathway. Mol. Med. Rep. 2020, 21, 1077-1088. [CrossRef]

206. Zhao, X.; Wang, T.; Cai, B.; Wang, X.; Feng, W.; Han, Y.; Li, D.; Li, S.; Liu, J. MicroRNA-495 Enhances Chondrocyte Apoptosis, Senescence and Promotes the Progression of Osteoarthritis by Targeting AKT1. Am. J. Transl. Res. 2019, 11, 2232-2244. [PubMed]

207. Yang, D.-W.; Qian, G.-B.; Jiang, M.-J.; Wang, P.; Wang, K.-Z. Inhibition of MicroRNA-495 Suppresses Chondrocyte Apoptosis through Activation of the NF-KB Signaling Pathway by Regulating CCL4 in Osteoarthritis. Gene Ther. 2019, 26, 217-229. [CrossRef] [PubMed]

208. Miao, G.; Zang, X.; Hou, H.; Sun, H.; Wang, L.; Zhang, T.; Tan, Y.; Liu, W.; Ye, P.; Gao, L.; et al. Bax Targeted by MiR-29a Regulates Chondrocyte Apoptosis in Osteoarthritis. BioMed Res. Int. 2019, 2019, e1434538. [CrossRef] [PubMed]

209. Jin, L.; Zhao, J.; Jing, W.; Yan, S.; Wang, X.; Xiao, C.; Ma, B. Role of MiR-146a in Human Chondrocyte Apoptosis in Response to Mechanical Pressure Injury in Vitro. Int. J. Mol. Med. 2014, 34, 451-463. [CrossRef]

210. Makki, M.S.; Haqqi, T.M. MiR-139 Modulates MCPIP1/IL-6 Expression and Induces Apoptosis in Human OA Chondrocytes. Exp. Mol. Med. 2015, 47, e189. [CrossRef]

211. Ma, Y.; Wu, Y.; Chen, J.; Huang, K.; Ji, B.; Chen, Z.; Wang, Q.; Ma, J.; Shen, S.; Zhang, J. MiR-10a-5p Promotes Chondrocyte Apoptosis in Osteoarthritis by Targeting HOXA1. Mol. Ther. Nucleic Acids 2019, 14, 398-409. [CrossRef]

212. Fu, M.; Huang, G.; Zhang, Z.; Liu, J.; Zhang, Z.; Huang, Z.; Yu, B.; Meng, F. Expression Profile of Long Noncoding RNAs in Cartilage from Knee Osteoarthritis Patients. Osteoarthr. Cartil. 2015, 23, 423-432. [CrossRef]

213. Liu, Q.; Zhang, X.; Dai, L.; Hu, X.; Zhu, J.; Li, L.; Zhou, C.; Ao, Y. Long Noncoding RNA Related to Cartilage Injury Promotes Chondrocyte Extracellular Matrix Degradation in Osteoarthritis. Arthritis Rheum. 2014, 66, 969-978. [CrossRef] [PubMed]

214. Razmara, E.; Bitaraf, A.; Yousefi, H.; Nguyen, T.H.; Garshasbi, M.; Cho, W.C.-S.; Babashah, S. Non-Coding RNAs in Cartilage Development: An Updated Review. Int. J. Mol. Sci. 2019, 20, 4475. [CrossRef] [PubMed]

215. Xi, Y.; Jiang, T.; Wang, W.; Yu, J.; Wang, Y.; Wu, X.; He, Y. Long Non-Coding HCG18 Promotes Intervertebral Disc Degeneration by Sponging MiR-146a-5p and Regulating TRAF6 Expression. Sci. Rep. 2017, 7, 13234. [CrossRef] [PubMed]

216. Song, J.; Ahn, C.; Chun, C.-H.; Jin, E.-J. A Long Non-Coding RNA, GAS5, Plays a Critical Role in the Regulation of MiR-21 during Osteoarthritis. J. Orthop. Res. 2014, 32, 1628-1635. [CrossRef]

217. Xing, D.; Liang, J.; Li, Y.; Lu, J.; Jia, H.; Xu, L.; Ma, X. Identification of Long Noncoding RNA Associated with Osteoarthritis in Humans. Orthop. Surg. 2014, 6, 288-293. [CrossRef] 
218. Zhang, C.; Wang, P.; Jiang, P.; Lv, Y.; Dong, C.; Dai, X.; Tan, L.; Wang, Z. Upregulation of LncRNA HOTAIR Contributes to IL-1 $\beta$-Induced MMP Overexpression and Chondrocytes Apoptosis in Temporomandibular Joint Osteoarthritis. Gene 2016, 586, 248-253. [CrossRef]

219. Watson, E.C.; Grant, Z.L.; Coultas, L. Endothelial Cell Apoptosis in Angiogenesis and Vessel Regression. Cell. Mol. Life Sci. 2017, 74, 4387-4403. [CrossRef]

220. Slomp, J.; Gittenberger-de Groot, A.C.; Glukhova, M.A.; Conny van Munsteren, J.; Kockx, M.M.; Schwartz, S.M.; Koteliansky, V.E. Differentiation, Dedifferentiation, and Apoptosis of Smooth Muscle Cells during the Development of the Human Ductus Arteriosus. Arterioscler. Thromb. Vasc. Biol. 1997, 17, 1003-1009. [CrossRef]

221. Cho, A.; Courtman, D.W.; Langille, B.L. Apoptosis (Programmed Cell Death) in Arteries of the Neonatal Lamb. Circ. Res. 1995, 76, 168-175. [CrossRef]

222. Durham, A.L.; Speer, M.Y.; Scatena, M.; Giachelli, C.M.; Shanahan, C.M. Role of Smooth Muscle Cells in Vascular Calcification: Implications in Atherosclerosis and Arterial Stiffness. Cardiovasc. Res. 2018, 114, 590-600. [CrossRef]

223. Grootaert, M.O.J.; Moulis, M.; Roth, L.; Martinet, W.; Vindis, C.; Bennett, M.R.; De Meyer, G.R.Y. Vascular Smooth Muscle Cell Death, Autophagy and Senescence in Atherosclerosis. Cardiovasc. Res. 2018, 114, 622-634. [CrossRef] [PubMed]

224. Tao, Y.K.; Shi, J.; Yu, P.L.; Zhang, G.Q. The Role of Endoplasmic Reticulum Stress-Related Apoptosis in Vascular Endothelium Pathogenesis. Biomed. Environ. Sci. 2018, 31, 555-559. [CrossRef] [PubMed]

225. Fang, K.; Chen, Z.; Liu, M.; Peng, J.; Wu, P. Apoptosis and Calcification of Vascular Endothelial Cell under Hyperhomocysteinemia. Med. Oncol. 2015, 32, 403. [CrossRef] [PubMed]

226. Johnson, R.C.; Leopold, J.A.; Loscalzo, J. Vascular Calcification: Pathobiological Mechanisms and Clinical Implications. Circ. Res. 2006, 99, 1044-1059. [CrossRef]

227. van Varik, B.J.; Rennenberg, R.J.M.W.; Reutelingsperger, C.P.; Kroon, A.A.; de Leeuw, P.W.; Schurgers, L.J. Mechanisms of Arterial Remodeling: Lessons from Genetic Diseases. Front. Genet. 2012, 3, 290. [CrossRef]

228. Patel, J.J.; Bourne, L.E.; Davies, B.K.; Arnett, T.R.; MacRae, V.E.; Wheeler-Jones, C.P.; Orriss, I.R. Differing Calcification Processes in Cultured Vascular Smooth Muscle Cells and Osteoblasts. Exp. Cell Res. 2019, 380, 100-113. [CrossRef]

229. Voelkl, J.; Cejka, D.; Alesutan, I. An Overview of the Mechanisms in Vascular Calcification during Chronic Kidney Disease. Curr. Opin. Nephrol. Hypertens. 2019, 28, 289-296. [CrossRef]

230. Lee, H.Y.; Oh, B.H. Aging and Arterial Stiffness. Circ. J. 2010, 74, 2257-2262. [CrossRef]

231. Xu, J.; Shi, G.-P. Vascular Wall Extracellular Matrix Proteins and Vascular Diseases. Biochim. Biophys. Acta 2014, 1842, 2106-2119. [CrossRef]

232. Watson, K.E.; Parhami, F.; Shin, V.; Demer, L.L. Fibronectin and Collagen I Matrixes Promote Calcification of Vascular Cells in Vitro, Whereas Collagen IV Matrix Is Inhibitory. Arterioscler. Thromb. Vasc. Biol. 1998, 18, 1964-1971. [CrossRef]

233. Tyson, J.; Bundy, K.; Roach, C.; Douglas, H.; Ventura, V.; Segars, M.F.; Schwartz, O.; Simpson, C.L. Mechanisms of the Osteogenic Switch of Smooth Muscle Cells in Vascular Calcification: WNT Signaling, BMPs, Mechanotransduction, and EndMT. Bioengineering 2020, 7, 88. [CrossRef] [PubMed]

234. Rutkovskiy, A.; Lund, M.; Siamansour, T.S.; Reine, T.M.; Kolset, S.O.; Sand, K.L.; Ignatieva, E.; Gordeev, M.L.; Stensløkken, K.-O.; Valen, G.; et al. Mechanical Stress Alters the Expression of Calcification-Related Genes in Vascular Interstitial and Endothelial Cells. Interact. Cardiovasc. Thorac. Surg. 2019, 28, 803-811. [CrossRef] [PubMed]

235. Yuan, C.; Ni, L.; Zhang, C.; Hu, X.; Wu, X. Vascular Calcification: New Insights into Endothelial Cells. Microvasc. Res. 2020, 134, 104105. [CrossRef] [PubMed]

236. Mantella, L.-E.; Quan, A.; Verma, S. Variability in Vascular Smooth Muscle Cell Stretch-Induced Responses in 2D Culture. Vasc. Cell 2015, 7, 7. [CrossRef] [PubMed]

237. Herencia, C.; Rodríguez-Ortiz, M.E.; Muñoz-Castañeda, J.R.; Martinez-Moreno, J.M.; Canalejo, R.; Montes de Oca, A.; DíazTocados, J.M.; Peralbo-Santaella, E.; Marín, C.; Canalejo, A.; et al. Angiotensin II Prevents Calcification in Vascular Smooth Muscle Cells by Enhancing Magnesium Influx. Eur. J. Clin. Investig. 2015, 45, 1129-1144. [CrossRef]

238. Pescatore, L.A.; Gamarra, L.F.; Liberman, M. Multifaceted Mechanisms of Vascular Calcification in Aging. Arterioscler. Thromb. Vasc. Biol. 2019, 39, 1307-1316. [CrossRef]

239. Wang, S.-S.; Wang, C.; Chen, H. MicroRNAs Are Critical in Regulating Smooth Muscle Cell Mineralization and Apoptosis during Vascular Calcification. J. Cell Mol. Med. 2020. [CrossRef]

240. Liu, J.; Xiao, X.; Shen, Y.; Chen, L.; Xu, C.; Zhao, H.; Wu, Y.; Zhang, Q.; Zhong, J.; Tang, Z.; et al. MicroRNA-32 Promotes Calcification in Vascular Smooth Muscle Cells: Implications as a Novel Marker for Coronary Artery Calcification. PLoS ONE 2017, 12, e0174138. [CrossRef]

241. Fujita, H.; Yamamoto, M.; Ogino, T.; Kobuchi, H.; Ohmoto, N.; Aoyama, E.; Oka, T.; Nakanishi, T.; Inoue, K.; Sasaki, J. Necrotic and Apoptotic Cells Serve as Nuclei for Calcification on Osteoblastic Differentiation of Human Mesenchymal Stem Cells in Vitro. Cell Biochem. Funct. 2014, 32, 77-86. [CrossRef]

242. Proudfoot, D.; Shanahan, C.M. Biology of Calcification in Vascular Cells: Intima versus Media. Herz 2001, 26, 245-251. [CrossRef]

243. Duan, X.; Zhou, Y.; Teng, X.; Tang, C.; Qi, Y. Endoplasmic Reticulum Stress-Mediated Apoptosis Is Activated in Vascular Calcification. Biochem. Biophys. Res. Commun. 2009, 387, 694-699. [CrossRef] [PubMed]

244. Zhang, L.; Sun, H.; Liu, S.; Gao, J.; Xia, J. Glycemic Variability Is Associated with Vascular Calcification by the Markers of Endoplasmic Reticulum Stress-Related Apoptosis, Wnt1, Galectin-3 and BMP-2. Diabetol. Metab. Syndr. 2019, 11. [CrossRef] [PubMed] 
245. Cao, X.; Li, H.; Tao, H.; Wu, N.; Yu, L.; Zhang, D.; Lu, X.; Zhu, J.; Lu, Z.; Zhu, Q. Metformin Inhibits Vascular Calcification in Female Rat Aortic Smooth Muscle Cells via the AMPK-ENOS-NO Pathway. Endocrinology 2013, 154, 3680-3689. [CrossRef] [PubMed]

246. Ma, W.-Q.; Sun, X.-J.; Wang, Y.; Zhu, Y.; Han, X.-Q.; Liu, N.-F. Restoring Mitochondrial Biogenesis with Metformin Attenuates $\beta$-GP-Induced Phenotypic Transformation of VSMCs into an Osteogenic Phenotype via Inhibition of PDK4/Oxidative StressMediated Apoptosis. Mol. Cell. Endocrinol. 2019, 479, 39-53. [CrossRef]

247. Lu, Y.; Bian, Y.; Wang, Y.; Bai, R.; Wang, J.; Xiao, C. Globular Adiponectin Reduces Vascular Calcification via Inhibition of ER-Stress-Mediated Smooth Muscle Cell Apoptosis. Int. J. Clin. Exp. Pathol. 2015, 8, 2545-2554.

248. Ross, R. Atherosclerosis-An Inflammatory Disease. N. Engl. J. Med. 1999, 340, 115-126. [CrossRef]

249. Mallat, Z.; Tedgui, A. Apoptosis in the Vasculature: Mechanisms and Functional Importance. Br. J. Pharmacol. 2000, 130, 947-962. [CrossRef]

250. Ghosh, S.; Luo, D.; He, W.; Chen, J.; Su, X.; Huang, H. Diabetes and Calcification: The Potential Role of Anti-Diabetic Drugs on Vascular Calcification Regression. Pharmacol. Res. 2020, 158, 104861. [CrossRef]

251. Ziyad, A.-A. Arterial Calcification: A Tumor Necrosis Factor-Alpha Mediated Vascular Wnt-Opathy. Transl. Res. 2008, 151, 233-239. [CrossRef]

252. Lee, K.-M.; Kang, H.-A.; Park, M.; Lee, H.-Y.; Choi, H.-R.; Yun, C.-H.; Oh, J.-W.; Kang, H.-S. Interleukin-24 Attenuates $\beta$ Glycerophosphate-Induced Calcification of Vascular Smooth Muscle Cells by Inhibiting Apoptosis, the Expression of Calcification and Osteoblastic Markers, and the Wnt/ $\beta$-Catenin Pathway. Biochem. Biophys. Res. Commun. 2012, 428, 50-55. [CrossRef]

253. Makarović, S.; Makarović, Z.; Steiner, R.; Mihaljević, I.; Milas-Ahić, J. Osteoprotegerin and Vascular Calcification: Clinical and Prognostic Relevance. Coll. Antropol. 2015, 39, 461-468. [PubMed]

254. Scatena, M.; Almeida, M.; Chaisson, M.L.; Fausto, N.; Nicosia, R.F.; Giachelli, C.M. NF-KappaB Mediates Alphavbeta3 IntegrinInduced Endothelial Cell Survival. J. Cell Biol. 1998, 141, 1083-1093. [CrossRef] [PubMed]

255. Zheng, B.; Clemmons, D.R. Blocking Ligand Occupancy of the AlphaVbeta3 Integrin Inhibits Insulin-like Growth Factor I Signaling in Vascular Smooth Muscle Cells. Proc. Natl. Acad. Sci. USA 1998, 95, 11217-11222. [CrossRef] [PubMed]

256. Strömblad, S.; Becker, J.C.; Yebra, M.; Brooks, P.C.; Cheresh, D.A. Suppression of P53 Activity and P21WAF1/CIP1 Expression by Vascular Cell Integrin AlphaVbeta3 during Angiogenesis. J. Clin. Investig. 1996, 98, 426-433. [CrossRef]

257. Carmeliet, P.; Lampugnani, M.G.; Moons, L.; Breviario, F.; Compernolle, V.; Bono, F.; Balconi, G.; Spagnuolo, R.; Oosthuyse, B.; Dewerchin, M.; et al. Targeted Deficiency or Cytosolic Truncation of the VE-Cadherin Gene in Mice Impairs VEGF-Mediated Endothelial Survival and Angiogenesis. Cell 1999, 98, 147-157. [CrossRef]

258. Zanetti, A.; Lampugnani, M.G.; Balconi, G.; Breviario, F.; Corada, M.; Lanfrancone, L.; Dejana, E. Vascular Endothelial Growth Factor Induces SHC Association with Vascular Endothelial Cadherin: A Potential Feedback Mechanism to Control Vascular Endothelial Growth Factor Receptor-2 Signaling. Arterioscler. Thromb. Vasc. Biol. 2002, 22, 617-622. [CrossRef]

259. Jones, P.L.; Crack, J.; Rabinovitch, M. Regulation of Tenascin-C, a Vascular Smooth Muscle Cell Survival Factor That Interacts with the Alpha v Beta 3 Integrin to Promote Epidermal Growth Factor Receptor Phosphorylation and Growth. J. Cell Biol. 1997, 139, 279-293. [CrossRef]

260. Rüegg, C.; Yilmaz, A.; Bieler, G.; Bamat, J.; Chaubert, P.; Lejeune, F.J. Evidence for the Involvement of Endothelial Cell Integrin AlphaVbeta3 in the Disruption of the Tumor Vasculature Induced by TNF and IFN-Gamma. Nat. Med. 1998, 4, 408-414. [CrossRef]

261. Pollman, M.J.; Naumovski, L.; Gibbons, G.H. Vascular Cell Apoptosis: Cell Type-Specific Modulation by Transforming Growth Factor-Beta1 in Endothelial Cells versus Smooth Muscle Cells. Circulation 1999, 99, 2019-2026. [CrossRef]

262. Almeida, E.A.; Ilić, D.; Han, Q.; Hauck, C.R.; Jin, F.; Kawakatsu, H.; Schlaepfer, D.D.; Damsky, C.H. Matrix Survival Signaling: From Fibronectin via Focal Adhesion Kinase to c-Jun NH(2)-Terminal Kinase. J. Cell Biol. 2000, 149, 741-754. [CrossRef]

263. Cance, W.G.; Golubovskaya, V.M. Focal Adhesion Kinase versus P53: Apoptosis or Survival? Sci. Signal 2008, 1, pe22. [CrossRef] [PubMed]

264. Koyama, H.; Raines, E.W.; Bornfeldt, K.E.; Roberts, J.M.; Ross, R. Fibrillar Collagen Inhibits Arterial Smooth Muscle Proliferation through Regulation of Cdk2 Inhibitors. Cell 1996, 87, 1069-1078. [CrossRef]

265. Harrington, E.O.; Smeglin, A.; Newton, J.; Ballard, G.; Rounds, S. Protein Tyrosine Phosphatase-Dependent Proteolysis of Focal Adhesion Complexes in Endothelial Cell Apoptosis. Am. J. Physiol. Lung Cell Mol. Physiol. 2001, 280, L342-L353. [CrossRef] [PubMed]

266. Kaiser, D.; Freyberg, M.A.; Schrimpf, G.; Friedl, P. Apoptosis Induced by Lack of Hemodynamic Forces Is a General Endothelial Feature Even Occuring in Immortalized Cell Lines. Endothelium 1999, 6, 325-334. [CrossRef]

267. Zeng, Y.; Qiao, Y.; Zhang, Y.; Liu, X.; Wang, Y.; Hu, J. Effects of Fluid Shear Stress on Apoptosis of Cultured Human Umbilical Vein Endothelial Cells Induced by LPS. Cell Biol. Int. 2005, 29, 932-935. [CrossRef]

268. Dimmeler, S.; Haendeler, J.; Rippmann, V.; Nehls, M.; Zeiher, A.M. Shear Stress Inhibits Apoptosis of Human Endothelial Cells. FEBS Lett. 1996, 399, 71-74. [CrossRef]

269. Dimmeler, S.; Haendeler, J.; Nehls, M.; Zeiher, A.M. Suppression of Apoptosis by Nitric Oxide via Inhibition of Interleukin-1betaConverting Enzyme (ICE)-like and Cysteine Protease Protein (CPP)-32-like Proteases. J. Exp. Med. 1997, 185, 601-607. [CrossRef]

270. Siasos, G.; Tousoulis, D.; Siasou, Z.; Stefanadis, C.; Papavassiliou, A.G. Shear Stress, Protein Kinases and Atherosclerosis. Curr. Med. Chem. 2007, 14, 1567-1572. [CrossRef]

271. Nicotera, P.; Bernassola, F.; Melino, G. Nitric Oxide (NO), a Signaling Molecule with a Killer Soul. Cell Death Differ. 1999, 6, 931-933. [CrossRef] 
272. Sagoo, P.; Chan, G.; Larkin, D.F.P.; George, A.J.T. Inflammatory Cytokines Induce Apoptosis of Corneal Endothelium through Nitric Oxide. Invest. Ophthalmol. Vis. Sci. 2004, 45, 3964-3973. [CrossRef]

273. Galis, Z.S.; Sukhova, G.K.; Lark, M.W.; Libby, P. Increased Expression of Matrix Metalloproteinases and Matrix Degrading Activity in Vulnerable Regions of Human Atherosclerotic Plaques. J. Clin. Investig. 1994, 94, 2493-2503. [CrossRef] [PubMed]

274. Mannello, F.; Luchetti, F.; Falcieri, E.; Papa, S. Multiple Roles of Matrix Metalloproteinases during Apoptosis. Apoptosis 2005, 10, 19-24. [CrossRef] [PubMed]

275. Mohan, M.J.; Seaton, T.; Mitchell, J.; Howe, A.; Blackburn, K.; Burkhart, W.; Moyer, M.; Patel, I.; Waitt, G.M.; Becherer, J.D.; et al. The Tumor Necrosis Factor-Alpha Converting Enzyme (TACE): A Unique Metalloproteinase with Highly Defined Substrate Selectivity. Biochemistry 2002, 41, 9462-9469. [CrossRef] [PubMed]

276. Bennett, M.R. Apoptosis in the Cardiovascular System. Heart 2002, 87, 480-487. [CrossRef] [PubMed]

277. Stoneman, V.E.A.; Bennett, M.R. Role of Fas/Fas-L in Vascular Cell Apoptosis. J. Cardiovasc. Pharmacol. 2009, 53, 100-108. [CrossRef]

278. Boyle, J.J.; Weissberg, P.L.; Bennett, M.R. Tumor Necrosis Factor-Alpha Promotes Macrophage-Induced Vascular Smooth Muscle Cell Apoptosis by Direct and Autocrine Mechanisms. Arterioscler. Thromb. Vasc. Biol. 2003, 23, 1553-1558. [CrossRef] [PubMed]

279. Aravani, D.; Foote, K.; Figg, N.; Finigan, A.; Uryga, A.; Clarke, M.; Bennett, M. Cytokine Regulation of Apoptosis-Induced Apoptosis and Apoptosis-Induced Cell Proliferation in Vascular Smooth Muscle Cells. Apoptosis 2020, 25, 648-662. [CrossRef]

280. Lindner, H.; Holler, E.; Ertl, B.; Multhoff, G.; Schreglmann, M.; Klauke, I.; Schultz-Hector, S.; Eissner, G. Peripheral Blood Mononuclear Cells Induce Programmed Cell Death in Human Endothelial Cells and May Prevent Repair: Role of Cytokines. Blood 1997, 89, 1931-1938. [CrossRef]

281. Karsan, A.; Yee, E.; Harlan, J.M. Endothelial Cell Death Induced by Tumor Necrosis Factor-Alpha Is Inhibited by the Bcl-2 Family Member, A1. J. Biol. Chem. 1996, 271, 27201-27204. [CrossRef]

282. Van Antwerp, D.J.; Martin, S.J.; Verma, I.M.; Green, D.R. Inhibition of TNF-Induced Apoptosis by NF-Kappa B. Trends Cell Biol. 1998, 8, 107-111. [CrossRef]

283. Badrichani, A.Z.; Stroka, D.M.; Bilbao, G.; Curiel, D.T.; Bach, F.H.; Ferran, C. Bcl-2 and Bcl-XL Serve an Anti-Inflammatory Function in Endothelial Cells through Inhibition of NF-KappaB. J. Clin. Investig. 1999, 103, 543-553. [CrossRef]

284. Forde, H.; Harper, E.; Davenport, C.; Rochfort, K.D.; Wallace, R.; Murphy, R.P.; Smith, D.; Cummins, P.M. The Beneficial Pleiotropic Effects of Tumour Necrosis Factor-Related Apoptosis-Inducing Ligand (TRAIL) within the Vasculature: A Review of the Evidence. Atherosclerosis 2016, 247, 87-96. [CrossRef]

285. Michowitz, Y.; Goldstein, E.; Roth, A.; Afek, A.; Abashidze, A.; Ben Gal, Y.; Keren, G.; George, J. The Involvement of Tumor Necrosis Factor-Related Apoptosis-Inducing Ligand (TRAIL) in Atherosclerosis. J. Am. Coll. Cardiol. 2005, 45, 1018-1024. [CrossRef]

286. Sato, K.; Niessner, A.; Kopecky, S.L.; Frye, R.L.; Goronzy, J.J.; Weyand, C.M. TRAIL-Expressing T Cells Induce Apoptosis of Vascular Smooth Muscle Cells in the Atherosclerotic Plaque. J. Exp. Med. 2006, 203, 239-250. [CrossRef]

287. Hofbauer, L.C.; Shui, C.; Riggs, B.L.; Dunstan, C.R.; Spelsberg, T.C.; O’Brien, T.; Khosla, S. Effects of Immunosuppressants on Receptor Activator of NF-KappaB Ligand and Osteoprotegerin Production by Human Osteoblastic and Coronary Artery Smooth Muscle Cells. Biochem. Biophys. Res. Commun. 2001, 280, 334-339. [CrossRef] [PubMed]

288. Lee, M.-S. Role of Mitochondrial Function in Cell Death and Body Metabolism. Front. Biosci. 2016, $21,1233-1244$. [CrossRef] [PubMed]

289. Shi, Y.; Wang, S.; Peng, H.; Lv, Y.; Li, W.; Cheng, S.; Liu, J. Fibroblast Growth Factor 21 Attenuates Vascular Calcification by Alleviating Endoplasmic Reticulum Stress Mediated Apoptosis in Rats. Int. J. Biol. Sci. 2019, 15, 138-147. [CrossRef] [PubMed]

290. Olapoju, S.O.; Adejobi, O.I.; Le Thi, X. Fibroblast Growth Factor 21; Review on Its Participation in Vascular Calcification Pathology. Vascul. Pharmacol. 2020, 125, 106636. [CrossRef]

291. García de la Cadena, S.; Massieu, L. Caspases and Their Role in Inflammation and Ischemic Neuronal Death. Focus on Caspase-12. Apoptosis 2016, 21, 763-777. [CrossRef]

292. Cao, F.; Liu, X.; Cao, X.; Wang, S.; Fu, K.; Zhao, Y.; Shen, F.; Liu, J. Fibroblast Growth Factor 21 Plays an Inhibitory Role in Vascular Calcification in Vitro through OPG/RANKL System. Biochem. Biophys. Res. Commun. 2017, 491, 578-586. [CrossRef]

293. Salvayre, R.; Auge, N.; Benoist, H.; Negre-Salvayre, A. Oxidized Low-Density Lipoprotein-Induced Apoptosis. Biochim. Biophys. Acta 2002, 1585, 213-221. [CrossRef]

294. Sata, M.; Walsh, K. Oxidized LDL Activates Fas-Mediated Endothelial Cell Apoptosis. J. Clin. Investig. 1998, 102, 1682-1689. [CrossRef] [PubMed]

295. Harada, K.; Ishibashi, S.; Miyashita, T.; Osuga, J.; Yagyu, H.; Ohashi, K.; Yazaki, Y.; Yamada, N. Bcl-2 Protein Inhibits OxysterolInduced Apoptosis through Suppressing CPP32-Mediated Pathway. FEBS Lett. 1997, 411, 63-66. [CrossRef]

296. Escargueil-Blanc, I.; Meilhac, O.; Pieraggi, M.T.; Arnal, J.F.; Salvayre, R.; Nègre-Salvayre, A. Oxidized LDLs Induce Massive Apoptosis of Cultured Human Endothelial Cells through a Calcium-Dependent Pathway. Prevention by Aurintricarboxylic Acid. Arterioscler. Thromb. Vasc. Biol. 1997, 17, 331-339. [CrossRef] [PubMed]

297. Geng, Y.J.; Wu, Q.; Muszynski, M.; Hansson, G.K.; Libby, P. Apoptosis of Vascular Smooth Muscle Cells Induced by in Vitro Stimulation with Interferon-Gamma, Tumor Necrosis Factor-Alpha, and Interleukin-1 Beta. Arterioscler. Thromb. Vasc. Biol. 1996, 16, 19-27. [CrossRef]

298. Bennett, M.R.; Boyle, J.J. Apoptosis of Vascular Smooth Muscle Cells in Atherosclerosis. Atherosclerosis 1998, 138, 3-9. [CrossRef] 
299. Mallat, Z.; Heymes, C.; Ohan, J.; Faggin, E.; Lesèche, G.; Tedgui, A. Expression of Interleukin-10 in Advanced Human Atherosclerotic Plaques: Relation to Inducible Nitric Oxide Synthase Expression and Cell Death. Arterioscler. Thromb. Vasc. Biol. 1999, 19, 611-616. [CrossRef]

300. Pollman, M.J.; Yamada, T.; Horiuchi, M.; Gibbons, G.H. Vasoactive Substances Regulate Vascular Smooth Muscle Cell Apoptosis. Countervailing Influences of Nitric Oxide and Angiotensin II. Circ. Res. 1996, 79, 748-756. [CrossRef]

301. Haendeler, J.; Weiland, U.; Zeiher, A.M.; Dimmeler, S. Effects of Redox-Related Congeners of NO on Apoptosis and Caspase-3 Activity. Nitric Oxide 1997, 1, 282-293. [CrossRef]

302. Kim, Y.M.; Bombeck, C.A.; Billiar, T.R. Nitric Oxide as a Bifunctional Regulator of Apoptosis. Circ. Res. 1999, 84, 253-256. [CrossRef]

303. Yamada, T.; Akishita, M.; Pollman, M.J.; Gibbons, G.H.; Dzau, V.J.; Horiuchi, M. Angiotensin II Type 2 Receptor Mediates Vascular Smooth Muscle Cell Apoptosis and Antagonizes Angiotensin II Type 1 Receptor Action: An in Vitro Gene Transfer Study. Life Sci. 1998, 63, PL289-PL295. [CrossRef]

304. Leeper, N.J.; Maegdefessel, L. Non-Coding RNAs: Key Regulators of Smooth Muscle Cell Fate in Vascular Disease. Cardiovasc. Res. 2018, 114, 611-621. [CrossRef] [PubMed]

305. Zhang, B.; Zhang, G.; Wei, T.; Yang, Z.; Tan, W.; Mo, Z.; Liu, J.; Li, D.; Wei, Y.; Zhang, L.; et al. MicroRNA-25 Protects Smooth Muscle Cells against Corticosterone-Induced Apoptosis. Oxid. Med. Cell Longev. 2019, 2019, 2691514. [CrossRef] [PubMed]

306. Tan, K.O.; Tan, K.M.; Chan, S.L.; Yee, K.S.; Bevort, M.; Ang, K.C.; Yu, V.C. MAP-1, a Novel Proapoptotic Protein Containing a BH3-like Motif That Associates with Bax through Its Bcl-2 Homology Domains. J. Biol. Chem. 2001, 276, 2802-2807. [CrossRef]

307. Zhang, L.; Cheng, H.; Yue, Y.; Li, S.; Zhang, D.; He, R. H19 Knockdown Suppresses Proliferation and Induces Apoptosis by Regulating MiR-148b/WNT/ $\beta$-Catenin in Ox-LDL -Stimulated Vascular Smooth Muscle Cells. J. Biomed. Sci. 2018, 25, 11. [CrossRef]

308. Zhang, L.; Cheng, H.; Yue, Y.; Li, S.; Zhang, D.; He, R. TUG1 Knockdown Ameliorates Atherosclerosis via Up-Regulating the Expression of MiR-133a Target Gene FGF1. Cardiovasc. Pathol. 2018, 33, 6-15. [CrossRef]

309. Wu, X.; Zheng, X.; Cheng, J.; Zhang, K.; Ma, C. LncRNA TUG1 Regulates Proliferation and Apoptosis by Regulating MiR148b/IGF2 Axis in Ox-LDL-Stimulated VSMC and HUVEC. Life Sci. 2020, 243, 117287. [CrossRef]

310. Peng, Y.; Meng, K.; Jiang, L.; Zhong, Y.; Yang, Y.; Lan, Y.; Zeng, Q.; Cheng, L. Thymic Stromal Lymphopoietin-Induced HOTAIR Activation Promotes Endothelial Cell Proliferation and Migration in Atherosclerosis. Biosci. Rep. 2017, 37. [CrossRef] 